\title{
OLASZ Lajos* \\ Az ejtőernyős elhárítás megszervezése Magyarország hadba lépését követően \\ 1941-1942.
}

(Organizing Paratrooper Countermeasures following Hungary’s Entry into War

1941-1942)

Absztrakt

1941. VI. és 1942. I. között szovjet ejtőernyős csoportokat dobtak le Kárpátaljára és Észak Erdélyre. Ezeket a rendvédelem és az újonnan megszervezett ejtőernyős elhárító szolgálat gyorsan felszámolta. Az akciók sikertelensége és a front eltávolodása miatt újabb csoportok bevetésére 1943 nyarától került sor. 1944. V. és VIII. között mintegy 25 szovjet ejtőernyős csoportot vetettek be. Bár a honvédség egységei is fokozottabb szerepet vállaltak az ellenséges ejtőernyősök elleni harcban, az továbbra is alapvetően a rendvédelmi szervekre, mindenekelött a csendőrségre hárult.

1944 ben nagyobb létszámú csoportokat dobtak le, amelyek sikeres megkapaszkodás esetén további erősítést kaptak. Megnőtt a partizánok tủzereje. Nagyobb hangsúlyt kapott a helyi lakosság körében folytatott agitáció, toborzás, és a felderítés. A kellő erő biztosítása érdekében a központi csendőr zászlóaljak, tanosztályok egy-egy fegyverzetileg megerősített részlegét kihelyezték a veszélyeztetett körzetekbe. A rendvédelemi szervek felszámolták vagy kiszorították az ország területére érkező csoportok többségét, ennek során azonban érzékeny veszteségeket szenvedtek el.

\author{
Kulcsszavak \\ Rendvédelem ; Ejtőernyős csoportok ; közbiztonság ; határsértés ; Magyarország 1941-1942
}

Abstract

Between June 1941 and January 1942, Soviet paratroopers parachuted into Subcarpathia and Northern Transylvania. These were quickly liquidated by law enforcement and the newly organized anti-paratrooper service. Because of the failure of these actions and the regression of the front, new paratroopers were sent in summer 1943. Between May and August 1944, approximately 25 Soviet paratrooper units were deployed. Although the units of the army played an increasing role in the fight against the paratroopers of the enemy, it was still mainly the responsibility of law enforcement organizations, foremost of the gendarmerie.

In 1944, larger numbers of paratroopers were deployed. If meeting with success, they received additional support. The firepower of the partisans became greater. Among local residents, agitation, recruitment and discovery were more greatly emphasized. In the interests of fielding a sufficiently strong resistance, central command of the gendarmerie placed fully armed sections of battalions and/or classes into vulnerable areas. Although suffering sensitive losses, law enforcement organizations destroyed or forced most of the invading paratroopers to retreat from Hungary.

Key words:

Law enforcement ; paratroopers ; public safety ; border violation ； Hungary 1941-1942

A

II. világháború kirobbanásakor Magyarországon nem volt érvényben átfogó szabályozás az ellenséges ejtőernyősök elhárítására vonatkozóan. Az ejtőernyős hadviseléssel kapcsolatban a háború elején még nem voltak tapasztalatok. Katonai jelentőségét csak a későbbi háborús események mutatták meg. A Magyarországgal konfliktusban álló szomszédos államok (Szlovákia, Románia, Jugoszlávia) számottevő ejtőernyős erővel nem rendelkeztek. Az ejtőernyős elhárítás kiépítése így 1941-ig nem tűnt sürgetőnek. A Szovjetunió elleni német felvonulás nyomán azonban a magyar katonai vezetés szükségesnek látta, hogy Magyarország is felkészüljön az ekkora már szélesebb körben alkalmazott légi szállítású támadó egységek elhárítására. Különösen, mert közismert volt, hogy a szovjet haderő nagy figyelmet fordított erre a harcmodorra, a Vörös Hadsereg jelentős deszant kötelékekkel rendelkezett, és a polgári lakosság körében is sokan kaptak ejtőernyős kiképzést. ${ }^{1}$

\section{Lépések az ejtőernyős elhárítás országos megszervezésére}

1941. VI. 19-én a Honvéd Vezérkar Fönöke (VKF) értekezletet hívott össze az ejtőernyős elhárítás megszervezésének megbeszélésére, mert korábban ez a terület a Magyar Királyi Honvédelmi Minisztérium (HM) vagy a VKF egyik osztályának ügykörébe sem tartozott. Az értekezletre 1941. VI. 20án került sor. A megbeszélésen döntés született arról, hogy az ejtőernyő elhárítás (ejel.) megszervezése és irányítása — az I. légvédelmi hadtest szakmai javaslatainak figyelembe vételével —a HM VI. csoportfőnöksége, illetve annak 35. (légoltalmi) osztálya illetékességébe kerül. ${ }^{2}$ Az ellenséges ejtőernyősök megfigyelése elsődlegesen a légvédelmi figyelő és jelentő szolgálat feladatkörébe tartozott. Ez katonai szervezet volt, amely mind a katonai légvédelmet, mind a polgári légoltalmat ellátta a légtérben zajló eseményekre vonatkozó információkkal. ${ }^{3}$

Az értekezleten megállapították, hogy alapvetően kétféle ejtőernyős tevékenységgel kell számolni: egyrészt, egyes felderítők, kémek, agitátorok, másrészt, kisebb, szabotázs cselekményeket

\footnotetext{
"Open Researcher and Contributor ID = Nyílt Kutató és Közremüködő Azonosító (ORCID) : https://orcid.org/0000-0002-4463-3251 Institutional attachements $=$ Szerző intézményi kötödései :

- University of Sciences Szeged Faculty of Education

- Hungarian Historical Society

- Hungarian Military Science Society

= Szegedi Tudományegyetem Pedagógusképző Kar

= Magyar Történelmi Társulat

= Magyar Hadtudományi Társaság

@: olasz@jgypku-szeged.hu
} 
végrehajtó romboló osztagok bevetésével. Az ellenséges ejtőernyősök semlegesítésére kijelölt katonai alakulatok konkrét alkalmazása a VKF hatáskörébe tartozott. Az értekezlet után utasították a HM VI. csoportfönökét — aki egyben az I. légvédelmi hadtest parancsnoki feladatait is ellátta $-{ }^{4}$ hogy haladéktalanul dolgoztasson ki tervezetet az ejtőernyős elhárítás országos kiépítésére vonatkozóan. A honvédelmi tárca vezetője pedig elrendelte, hogy a HM érintett osztályai az ejtőernyős elhárítással öszszefüggő ügyeket sürgősséggel, soron kívül intézzék. ${ }^{5}$

1941. VI. 22-én megindult a Szovjetunió elleni német támadás. Magyarország egyelőre nem vett részt a hadmúveletekben, de a határok mentén dúló háború miatt óvintézkedéseket hajtott végre. Elrendelték a katonai légvédelmi készültséget, müködésbe lépett a figyelő, jelentő és riasztó szolgálat. A polgári légoltalom számára csak könnyített készültségi fokozatot vezettek be. Ez a légoltalom teljes személyi állománynak csak egytizedére terjedt ki, a települések és intézmények parancsnoki törzsei, és egy-egy ügyeletes tüzoltó, mentő és kárfelszámoló egység készültségbe helyezésével. ${ }^{6}$

1941. VI. 25-én a HM 35. osztálya újabb értekezletet szervezett, ahol az ejtőernyős elhárítás részleteit beszélték meg. Itt összegezték azokat az alapelveket, amelyre az elhárító szolgálat épült. A tevékenység során két feladatkört különítettek el, a megfigyelést és az elhárítást. A megfigyelés országos szerve, a légvédelmi figyelő és jelentő szolgálat a visszacsatolt keleti országrészben még csak a kiépítés kezdetén állt. Kárpátalján, a Munkácsi 9. Légvédelmi Központ 39 kijelölt figyelő őrse közül még csak 20 müködött, az is csökkentett létszámmal, még nem automatizált, hanem manuális hírközlö rendszerrel. Észak-Erdélyben a tervezett négy kerületi központból még egyet sem állítottak fel. A hosszú határvonal mentén, a nagy kiterjedésủ országrészben, mindössze 16 figyelö őrs müködött, melyek a kolozsvári IX. hadtest-parancsnokságnak jelentettek, onnan továbbították az információkat az Országos Légvédelmi Központnak, Budapestre. ${ }^{7}$

Ezért első lépésként meg kellett szervezni a polgári ejtőernyős figyelő szolgálatot, amelyet — a légoltalmi szolgálathoz hasonlóan, annak — kiegészítéseként föként nem sorköteles férfiakból, cserkészekböl, leventékből hoztak létre. A honvédelmi törvény lehetővé tette, hogy a lakosság nagy részét szükség esetén honvédelmi munkakötelezettség címén igénybe vegyék. Ennek részét képezte a személyes, illetve különleges légvédelmi szolgálat, amely az országos vagy helyi légvédelmi figyelő őrsökbe vagy más légoltalmi feladatkörökbe való beosztást jelentette, valamint egyéb közérdekủ igénybevétellel járt, mint a külterület ellenőrzése, a mezőgazdasági termés tüzvédelme. A polgári lakosságot felszólították, hogy minden rendkívüli eseményről, vagy váratlanul felbukkanó gyanús személyről haladéktalanul tájékoztassák a hatóságokat. A bejelentési kötelezettség elmulasztása esetére szigorú szankciókat helyeztek kilátásba. ${ }^{8}$

Mivel az ellenséges ejtőernyősök leszállása elsősorban a lakatlan külterületen volt várható, az elhárítás elsősorban a rendvédelmi szervekre hárult. A honvédelmi és a belügyi tárca egyeztetése nyomán úgy határoztak, hogy az ejtőernyős elhárítás elsődleges operatív testülete a csendőrség lesz, amely egységes honvédségi irányítás mellett, szükség esetén (nagyobb csoportok leszállásakor) katonai alakulatok bevonásával, más esetekben pedig különböző hatósági személyek és társadalmi szervezetek mozgósításával látja el ezt a feladatot. A csendőr őrsök tüzerejének fokozása érdekében döntés született, hogy a honvédség hadizsákmányból származó golyószórókat ad át. A VII. (miskolci) csendőrkerület például 30 golyószórót kapott. Kezelésükre őrsönként 2-2 főt központilag kiképeztek, akik később saját őrseiken a legénység más tagjait is felkészítették a fegyverek használatára. ${ }^{9}$

A csendőrség az ejtőernyősök elhárításában támaszkodhatott a tüzharcosokból, polgári lövészekből, települési polgárőrökből, illetve cserkészekből és leventékből felállított ejtőernyős elhárító szolgálatra, amelyet főként a nagyobb területek átkutatására, utak lezárására, igazoltatásra, illetve magányos ejtőernyősök elfogására vettek igénybe. Nagyobb létszámú diverzáns csoport földre szállása esetén mindig kivezényelték a honvéd karhatalmat is. ${ }^{\mathbf{1 0}}$

Az ejtőernyősökre vonatkozó megfigyelést azonnal továbbítani kellett, a legközelebbi csendőr, rendőr vagy pénzügyőr szervhez, illetve katonai parancsnoksághoz. Ezért az „ejtőernyős beszélgetés” jelszó bemondása esetén a posta ingyenes hívást és elsőbbséget biztosítson a telefonálónak, szükség esetén bontva a vonalat lefoglaló más beszélgetéseket. Ilyen jelentések továbbítására a polgári személyek kivételesen igénybe vehették a Magyar Államvasútak (MÁV) telefon és távíró vonalait is. Az ellenséges ejtőernyősök leszállásról érkező hírek nyomán a helyileg illetékes honvéd állomás-parancsnokság, ,ejtőernyős riadót” rendelt el az elhárító szolgálatban résztvevő szervezetek számára. A kisebb településeken, ahol nem volt katonai parancsnokság, a csendörség mozgósította az elhárító egységeket. Ahol sem csendőr őrs, sem más fegyveres szervezet nem volt, ott a község elöljárósága 
jelölt ki egy arra alkalmas személyt (lövész, erdőőr), aki megszervezte és riasztotta a helyi elhárító osztagot. ${ }^{11}$

1941. VI. 25-én a HM 35. osztálya részletes tájékoztatást adott ki a városok és községek légoltalmi vezetői számára a mezőgazdasági területek ellen várható gyújtótámadások elleni védekezéssel kapcsolatban. A Magyar Királyi Belügyminisztérium (BM) részletesen meghatározta ezen a téren a települési vezetők feladatait. A támadások semlegesítésére termésvédelmi szolgálatot kellett szervezni, amely feladata a repülő megfigyelés, a tüzfigyelés, riasztás és tüzoltás ellátása volt. A községi templomok tornyában, illetve a határ magasabb pontjain megfigyelő állásokat alakítottak ki, ahol 24 órás ügyeletet szerveztek. A határban folyamatosan cirkáltak a kerékpáros vagy lovas járőrök. A falvakban vagy az 5-6 tanyából kialakított külterületi körzetekben tủzvédelmi egységet szerveztek. A sajtó útján a lakosság legszélesebb körét tájékoztatták a veszélyről és a tennivalókról, a terményvédelmi szolgálatba beosztott embereket pedig a légoltalmi szervek és a tüzoltóság bevonásával tartott előadásokon készítették fel a feladatra. ${ }^{12}$

1941. VI. 27-én, az előző napon lezajlott Kassa elleni légitámadás nyomán, a magyar kormány bejelentette, hogy beállt a hadiállapot a Szovjetunióval. Ezzel Magyarország is háborús résztvevővé vált. A VKF intézkedett, hogy a hadtest-parancsnokságok haladéktalanul kezdjék meg az ejtőernyős elhárítás megszervezését. Az országos szabályozás megszületéséig adjanak ki ideiglenes irányelveket és léptessenek életbe átmeneti szabályozást az ejtőernyős elhárító szolgálat ellátására. Egyúttal kezdjék meg a honvédelmi munkakötelezettség címén behívott polgári személyek ejtőernyős elhárító kiképzését. Az ellenséges partizánok leküzdéséhez szervezett egységek számára zsákmányfegyvereket utaltak ki. Az elhárító osztagok szervezése és kiképzése a járási katonai parancsnokságok hatáskörébe tartozott. ${ }^{13}$

A miskolci VII. honvéd hadtest, a VII. csendőr kerület-parancsnoksággal egyeztetve, széleskörü intézkedéseket foganatosított az ejtőernyős elhárítás kiépítésével és müködésével kapcsolatban. Mivel az országos szabályozás késett, a kerület parancsnoka azzal a javaslattal fordult a HM 20. (csendörségi) osztályához, hogy a miskolci kerületben bevezetett intézkedéseket terjesszék ki az egész országra, de legalábbis is a legveszélyeztetettebb kárpátaljai és észak-erdélyi régiókra. ${ }^{14}$

A hadba lépést követő napokban szórványos szovjet légitámadásokra került sor magyar területek ellen. Ellenséges gépek felderítő berepüléseket hajtottak végre, néhány bombát dobtak le vagy fedélzeti fegyverekkel támadták a határ menti katonai létesítményeket, illetve vasúti berendezéseket. A magyar katonai szervek ejtőernyősök bevetésére is számítottak. Az újságokon keresztül felhívást intéztek a lakossághoz, hogy készüljön fel ellenséges ejtőernyősök leszállására, és ismertették, hogyan kell fellépni a megjelenésük esetén. ${ }^{15}$

Az első napokban számos téves lakossági bejelentés érkezett a hivatalos szervekhez. Az emberek az új helyzet, a háború okozta bizonytalanság, a sajtófelhívások hatása alá kerülve esetenként különböző légköri jelenségeket leszálló ejtőernyősnek véltek. Máskor, magyar gépek átrepülése nyomán tettek bejelentést arról, hogy valószínüleg ejtőernyős leszállás történhetett. 1941. VI. 27-én a nagymajtényi gyújtó- és robbanólőszer raktárban, ahol főként jugoszláv zsákmányanyagot tároltak súlyos robbanás történt ( 7 halott, 14 sérült). A kivizsgálás során ellenséges diverzió lehetősége is felmerült, mert nem sokkal a robbanás elött egy repülőgépet láttak körözni a raktár térségében. Kiderült azonban, hogy nem szovjet berepülésről volt szó, hanem a csepeli Repülő Kísérleti Intézet egyik gépe végzett időjárás-megfigyelést a térségben. ${ }^{16}$

1941. VI. 27-én délben Balatonszabadi határában leereszkedő ejtőernyősröl érkezett lakossági bejelentés. Az enyingi és a balatonújhelyi csendőr őrs, valamint az enyingi katonai parancsnokság egy osztaga azonnal kivonult a jelzett helyszínre, de senkit nem talált. A környéken dolgozó mezei munkások sem észleltek semmi gyanúsat. Kora délután Máriabesnyőről érkezett bejelentés a Légierők Parancsnokságához, hogy a község határában egy ejtőernyős ereszkedett le. A gödöllői kormányzói rezidencia közelsége nagy hangsúlyt adott ennek a hírnek. A kivonuló karhatalom azonban nem találta nyomát ellenségnek. ${ }^{17}$

Szovjet ejtőernyősök bevetésével nemcsak a hatóságok, hanem a kormánnyal szemben álló politikai és nemzetiségi körök is számoltak. Az illegalitásban müködő Kommunista Párt észak-erdélyi területi titkársága 1941. VI. 27-én délelőtt megbeszélést tartott Kolozsváron, ahol szóba került az is, hogy számolni kell szovjet ejtőernyősök érkezésére, és fel kell készülni a velük való kapcsolatba lépésre. Hasonló módon a délvidéki szerb lakosság körében a magyar hadba lépés után elterjedt, hogy szovjet ejtőernyősök leszállása várható. Ezeket a bizonytalan várakozásokat egyes hivatalos hírek is 
megerősítették. 1941. VI. 28-án este a magyar légvédelmi szervek értesítést kaptak a németektől, hogy Neusandez (Nowy Sacz) térségében, a Duklai hágótól nyugatra szovjet ejtőernyős bevetés történt. Ennek nyomán a VKF fokozott éberségre utasította a figyelő és jelentő szolgálatot. ${ }^{18}$

Az ellenséges ejtőernyősökkel kapcsolatos bizonytalanság számos pontatlan, elhamarkodott, alap nélküli bejelentéshez vezetett. 1941. VI. 28-án délután a cigándi csendör őrs lakossági bejelentést továbbított, hogy Tiszakarád térségében 3 szovjet gép szállt le. Mivel a 7. (miskolci) Kerületi Légvédelmi Központ is kapott ilyen jelzést, az eset komolynak tünt, később azonban kiderült, hogy a magyar $1 / 1$. vadászrepülő osztály gépei hajtottak végre kényszerleszállást a térségben egyikük motorhibája miatt, majd folytatták az útjukat. A nógrádverőcei csendőr őrs ezen a napon olyan bejelentést kapott, hogy még 1941. VI. 26-án délután 3 ejtőernyőst látott leszállni az egyik lakos a községtől északra, 3 kilométerre. Magyarország ekkor még nem is állt hadiállapotban a Szovjetunióval. Az információt sürgősen továbbították a HM és a VKF illetékeseinek. Központi utasításra riadóztatták a környékbeli csendör őrsöket és a helyi lőszerraktár őrségét, az alapos kutatás ellenére a megadott térségben nem találták nyomát a jelzett ejtőernyősöknek. ${ }^{19}$

A feszült helyzetben tragikus baleset történt a pusztatenyői lőszerraktárnál, 1941. VI. 29-én éjszaka. Mivel két nappal korábban gyanús idegenekről érkezett bejelentés, elrendelték a környék átkutatását, melyben a raktár őrsége és a helyi csendőr őrs vett részt. Az együttmüködést azonban rosszul szervezték meg, a katonák és csendőrök egymást vélték ellenséges ejtőernyősnek. Az őrség parancsnoka a kutatás során elszakadt az általa vezetett osztagtól, amikor pedig a sötétben utolérte öket, az egyik fiatal katona rálött. A lövés a combartériát érte, az örparancsok a kórházba szállítás közben meghalt. ${ }^{20}$

1941. VI. 29-én délben a kisvárdai csendőrség jelentése szerint, Záhonytól délre, 10 km-re, Komoró és Tuzsér közelében szovjet ejtőernyősök leszállását észlelték. A jelentés ezúttal pontos volt, csak éppen nem ellenséges diverzánsok érkeztek magyar területre. A Csapot támadó szovjet kötelék 3 bombázóját lelőtte a magyar elhárítás, ezek személyzete menekült ejtőernyővel a zuhanó gépekből. Természetesen ezek elfogása is fontos volt, de földre szállásuk nem jelentett olyan veszélyt, mint a rombolási feladattal bevetett ejtőernyős osztagoké. ${ }^{21}$

Máig pontosan nem tisztázott a 1941. VI. 30-i szovjet ejtőernyős bevetés esete. A VIII. csendőr kerület jelentette a Magyar Királyi Csendőrség Központi Nyomozó Parancsnokságának és a HM 35. osztályának, hogy kora délután Rahótól északra a Mencsul-havasok térségében 12 ejtőernyőst láttak leszállni. A vasúti figyelőszolgálat jelzése alapján a Központi Szállításvezetőség ugyanilyen tartalmú tájékoztatást küldött a VKF 1. osztályának. Kárpátalja kiemelt jelentőséggel bírt a Szovjetunió elleni háborúba lépés után. Fontos út- és vasútvonalak mentek át rajta, köztük a Máramarossziget - Kolomea és a Munkács - Sztrij vonal, ami fontos szerepet játszott a magyar csapatok utánpótlásában. Egy ejtöernyős csoport tehát komoly nehézséget okozhatott az anyaország és a front közötti forgalom felderítésével és megzavarásával. ${ }^{22}$

A jelentések befutása után a kassai VIII. hadtest-parancsnokság azonnal elrendelte a közúti és vasúti mütárgyak karhatalmi őrségek által megvalósításra kerülő fokozott őrzését. Mozgósították a környékbeli csendőr őrsöket és megkezdték a kutatást. A VIII. csendőr kerület ${ }^{23}$ nagyobb erőket csoportosított át a kassai és nyíregyházi csendőr osztálytól, a máramarosszigeti csendőr osztály őrseinek megerősítésére. Számításba vették, hogy a magyarlakta területen lévő őrsök körzeteit megnövelik, így létszámot szabadítanak fel, melyet a kárpátaljai ruszin lakta területeken múködő rendvédelmi erők megerősítésére használhattak fel. A csendőr kerület parancsnoka ideiglenesen áttette a székhelyét az esemény helyszínéhez közelebb eső Beregszászba. A partizáncsoport azonban eltünt a kutatást végző magyar hatóságok szeme elől. Feltehetően átlépték a határt, mert feladatuk valószínűleg nem magyar, hanem német területre szólt. Az eset kapcsán, a várható ipari szabotázsakciók megelőzése érdekében a honvédség megerősítette az északkeleti országrészben működő nagyobb üzemek védelmét. ${ }^{24}$

Az ellenséges ejtőernyősök tevékenységét nagyban segíthette a helyi lakosság támogatása, a bújtatás, az élelmezés, az információval való ellátás. A kormány elrettentő erővel kívánt fellépni az ilyen jellegü magatartással szemben. 1941. VII. 1-jén a rögtönbíráskodást kiterjesztették a hütlenség büntettére is, így az egyébként a polgári bíráskodás hatálya alá tartozó személyek, ilyen esetekben a katonai büntetőbíróság hatáskörébe kerültek. Ezen a napon a VKF tájékoztatta a hadtest-parancsnokságokat, hogy a földművelésügyi miniszter egyetértésével az ejtőernyős figyelésbe bevonják a nagykiterjedésű külterületen tevékenykedö közhatósági jogkörrel felruházott személyeket és települési 
alkalmazottakat is (mezőőr, hegyőr, erdőőr, gátőr, zsilipőr, csatorna őr, legelőfelügyelő, útkaparó, csősz, pásztor). ${ }^{25}$

Az ejtőernyős leszállás pontos megfigyelése rendkívül fontos tényező volt, mert különben csak feleslegesen riasztották az elhárító szerveket, amelyek, különösen erdős-hegyes terepen nehezen akadtak rá a néhány fös ellenséges csoport nyomára. Ejtőernyősökről továbbra is számos bejelentés érkezett, ezek azonban csak kisebb részben tartalmaztak valós tényeket. 1941. VII. 1-jén leszálló szovjet repülőgépet jelentettek Királyháza közelében. Később kiderült, hogy a magyar 4. bombázóezred egyik Junkers Ju-86K bombázója volt. Lakossági bejelentés szerint 1941. VII. 1-jén este Poroszló körzetében polgári ruhás ejtőernyősök ereszkedtek le. Riasztották a poroszlói, mezőkövesdi, tiszafüredi csendőr-parancsnokságokat, valamint a Tisza hidak őrségét és az ott elhelyezett légvédelmi alakulatokat. Másnap reggel azonban a részletes csendőrségi kihallgatás során a bejelentő elismerte, hogy valójában nem látott ejtőernyősöket. ${ }^{26}$

Ugyanezen a napon a sepsiszentgyörgyi állomásfönök és a 109. számú vasúti parancsnokság közlése szerint 3 ejtőernyőst láttak leszállni Kálnok - Sepsibodok térségében. A kivezényelt katonai karhatalom és csendör járőrök nem találtak idegeneket a megadott körzetben. Ha a leszállás tényleg megtörtént, arra valószínüleg a határ közelében, vagy már román területen került sor, és az ejtőernyösök Dél-Erdély belseje felé távoztak. 1941. VII. 2-án délután, Nagykároly körzetében, Szaniszló községtől 5-6 kilométerre szintén ejtőernyősöket láttak leereszkedni. A helyszínre érkező 6-7 fős járőr parancsnoka úgy ítélte meg, hogy az ismeretlen számú és fegyverzetü, feltételezhetően az erdőbe húzódott partizánok ellen a kivonult erő kevés, ezért erősítést kért. A Nagykárolyból este kivezényelt honvéd karhatalom azonban a jelzett területen nem talált ellenséget. ${ }^{27}$

A hivatalos szervek tájékoztatásai sem voltak mentesek a tévedéstől. A zalaegerszegi állomásparancsnokság 1941. VII. 6-án arról tájékoztatta a szombathelyi III. hadtest parancsnokságát, hogy a várostól délre, 10 kilométerre, Sárhíd község határában 11 óra körül 3 szovjet ejtőernyős szállt le. A bucsuszentlászlói csendőr őrs 2 föt elfogott, 1 még szökésben van. Másfél órával később, részletesebb tájékozódás után azonban a III. hadtest már azt közölte a VKF illetékeseivel, hogy a korábbi, ejtőernyős leszállásról szóló híradás tévesnek bizonyult. ${ }^{28}$

\section{Ellenséges ejtőernyősök Magyarország területén}

Az ejtőernyős elhárítás első komoly fegyveres beavatkozására a 1941. VII. 8-án hajnalban, Szászrégen térségében leszállt szovjet ejtőernyős partizán osztag felszámolásakor került sor. Egy szovjet szállítógép 6 fö, román katonai egyenruhába öltözött ejtőernyőst dobott le, Szászrégentől északra, hajnali 3 óra körül. A leszállást senki sem látta, de 1941. VII. 8-án a portyázó csendőr járőr 2 cirill betüs felirattal ellátott ejtőernyőre, egy kézigránátra és egy bádogkulacsra bukkant, ami egyértelmúvé tette, hogy ejtőernyős leszállás történt. A 27. gyalogdandár parancsnoksága csendőrök és a polgári ejtőernyős elhárító szolgálat igénybevételével azonnal kutatást indított. 1941. VII. 9-én Lövér község határában elfogtak egy gyanús idegen személyt. Kihallgatása azonban nem vezetett eredményre, az illető gyengeelméjünek látszott. Később beigazolódott, hogy ő valóban nem ejtőernyős. 1941. VII. 10-én Görgénynádas és Hétbükk között egy szántóföldön, gabonával letakarva egy újabb ejtőernyőt találtak. Ettől nem messze, az 517. számú magasságpont közelében rábukkantak az ellenséges katonák által használt rejtekhelyre. Az ott talált gyufásdoboz, cigarettavégek egyértelmüen szovjet eredetre utaltak. $^{29}$

Másnap, a Székelyhodos és Deményháza közötti út mentén lakó juhász házába bekopogott egy idegen személy, az egyik ejtőernyős. Élelmet kért, és felvilágosítást, hogy pontosan hol van. Távozása után a juhász értesítette a csendőröket, a kiérkező járőr elől az ejtőernyős Jobbágytelke irányába menekült. Elfogására Marosvásárhelyröl kivezényelték a 27/III. honvéd zászlóalj egy századát, amely Nyárádremete határában felfedezte és bekerítette az idegent. Tüzharc alakult ki, amelyben az ejtőernyőst lelőtték. Az illető géppisztollyal és kézigránátokkal volt felfegyverezve. Hátizsákjában egy Romániát és Magyarországot ábrázoló térképet, valamint egy jegyzetfüzetet találtak, sok fontos információval. ${ }^{30}$

1941. VII. 14-én hírek érkeztek Szederjes körzetéből, ahol több, sötét színü idegen katonai egyenruhába öltözött alakot láttak. A 27. gyalogdandár parancsnokának irányításával a kutatást erre a térségre koncentrálták. A nap folyamán a karhatalmi erők a Mikóháza körüli erdőkben 3 ejtőernyősre bukkantak, akiket tüzharcban megöltek. Volt köztük egy föhadnagyi rendfokozatot viselő tiszt, valószínüleg a csoport parancsnoka. A harc során egy magyar hadnagy kézigránáttól sebesülést 
szenvedett. 1941. VII. 15-én, Marosvásárhely közelében, Nagyernye községben a honvédség elfogott egy ejtőernyőst. Kihallgatása során kiderült, hogy a csoportja 6 főből állt, tehát már csak 1 ejtőernyős bujkál. Mivel annak egyelöre nem akadtak nyomára, 1941. VII. 18-án a honvéd csapatokat kivonták a keresésből, a magányos ejtőernyős elfogását a csendőrségre és a polgári karhatalomra bízták. 1941. VII. 20-án esete 20 órakor, Nyárádköszvényes határában a csendőrök el is fogták az utolsó ejtőernyőst. ${ }^{31}$

A kihallgatási adatokból kiderült, hogy a Fekete-tenger északi körzetéből 2 szállítógép indult útnak, az egyiken 6 román, a másikon 8 német egyenruhába öltözött ejtőernyőssel. A személyi felszerelés 1-1 10 lövéses Mauser-pisztolyból 2-4 kézigránátból, 20 dkg trotilból és gyutacsokból és 5 napi élelemből állt. Mindkét csoportnak volt egy rádió adóvevője és egy géppisztolya is. A bevetés célterülete Románia, a Brassó melletti Földvár község térsége volt. A feladatuk Brassó katonailag fontos üzemei, a repülőgépgyár, a Schill-gépgyár, a gázgyár, illetve a repülőtér, a helyi laktanyák, a pályaudvar, illetve a sinajai alagút elleni szabotázsakciók végrehajtása volt. Érintkezésbe kellett lépniük a repülőgyárban dolgozó 12 kommunista munkással, és a lakosság körében kisebb ellenálló csoportokat kellett szervezniük. Szükség esetén fegyver és robbanóanyag utánpótlást Odesszából kérhettek rádión, amit repülögépről dobtak volna le nekik. ${ }^{32}$

A tervekhez képest a román egyenruhás csoportot szállító gép nagy mértékben eltért az útiránytól, és a csoportot a célterülettől 130 kilométerre, északra dobta le. A leszállás során az ugrók szétszóródtak, és a felszerelésük egy részét elvesztették. 2-3 napi keresés után talált egymásra 3, illetve 2 fö, füttyel, jelszó és jelhang bemondásával azonosították egymást. Ekkorra kiderült számukra, hogy rossz helyen vannak, ezért déli irányba, Brassó felé indultak, de a nappali rejtőzködés és a felszerelés cipelése miatt csak napi 15-20 kilométert tudtak megtenni. A csoport tagjai többségükben besszarábiai származású, románul is beszélö ukránok voltak. Speciális diverziós kiképzéssel csak 2 fő rendelkezett, a többi 4, frissen bevonult sorkatona mindössze 2 hetes földi ejtőernyős felkészítést kapott. Volt köztük, aki a bevetése napjáig még nem ült repülögépen. ${ }^{33}$

Bár a csoportot nem magyarországi célpont ellen vetették be, a megszerzett információk rendkívül fontosak voltak a Magyar Királyi Honvédség és a rendvédelmi szervek számára. Betekintést kaptak a szovjet ejtőernyős csoportok feladataiba, a bevetés végrehajtásába, az ejtőernyősök felszerelésébe, az általuk követett módszerekbe. A HM és a BM utasította saját közegeit, hogy készüljenek fel hasonló Magyarország elleni ejtőernyős akciókra, ahol, magyar katonai egyenruhába öltözött partizánok intéznek támadásokat közlekedési vagy hadiipari létesítmények ellen. Az ejtőernyős elhárításban résztvevő honvéd alakulatokat és a polgári ejtőernyős elhárítás szolgálatot is részletesen tájékoztatták, hogy az ilyen jellegü akciók ne érjék váratlanul őket. ${ }^{34}$

Az esetleges ellenséges légitámadások vagy ejtőernyős bevetések veszélye miatt az országos légvédelmi figyelő és jelentő hálózat fejlesztése terén előre vették az északkeleti országrészben lévő, még csak manuális üzemmódban müködő 9. munkácsi és 10. máramarosszigeti légvédelmi központ automatizálását. A HM 35. osztálya javaslatot tett az észak-erdélyi 11-13. légvédelmi központok kiépítésének felgyorsítására is. 1941. VII. 10-én a HM közleményt juttatott el az újságokhoz, amelyben az elmúlt hetek tapasztalatai alapján tájékoztatták a lakosságot, hogy hogyan kell fellépni ellenséges ejtőernyősökkel szemben, mi a civilek feladata ilyen esetben. A téves lakossági bejelentések számának csökkentése érdekében a szombathelyi III. hadtest azt kezdeményezte, hogy tiltsák be, vagy csak bizonyos körzetekre korlátozzák a vitorlázó repülést, mert a magasban lebegő gépek látványa csak felesleges izgalmat vált ki a lakosság körében, és álhír forrása lehet. ${ }^{35}$

Az ejtőernyős elhárítással kapcsolatos legfontosabb tudnivalók, a megfigyelés és elhárítás megszervezése, a megfelelő eljárás ismertetése érdekében az ellenséges csoportok által leginkább veszélyeztetett Észak-Erdély területén illetékes kolozsvári IX. honvéd hadtest ideiglenes segédletet állított össze. A 22 oldalas dokumentum hangsúlyozta, az egyes vagy kisebb csoportban érkező felderítők, romboló osztagok is komoly károkat tudnak okozni, ezért felszámolásuk elsődleges fontosságú. A leghatékonyabb megoldás, az ellenséges csoport közvetlen leszállás utáni megtámadása, megsemmisítése. Ehhez megbízható megfigyelésre van szükség. A földet ért partizánok ellen a helyi honvédelmi vagy rendvédelmi szervek minden rendelkezésre álló erővel lépjenek fel. Fegyveres összecsapás esetén a csendőr őrsök akár teljes állományát harcba kell vetni az ellenség semlegesítésére. A fegyveres elhárítást az egységes irányítás elve alapján az illetékes honvéd parancsnok, katonai erők hiányában a rangidős csendőr vezeti. A partizánok leküzdése a fegyveres szervezetek feladata, de szükség esetén bevonható ebbe a polgári karhatalom, felfegyverzett hatósági személyek, tüzharcos és lövész 
csoportok, lehetőleg azonban a civil lakosságot nem fegyveres, hanem összekötő, hírvivő szerepkörben célszerü alkalmazni. ${ }^{36}$

Az ejtőernyős elhárítás felkészültségének tesztelésére 1941. VII. 12-én az I. hadtest területén nagyszabású gyakorlatot tartottak. Ejtőernyővel ellátott homokzsákokat dobtak ki repülőgépről PestPilis-Solt-Kiskun vármegye több körzetében, hogy a figyelőszolgálat éberségét, a megfigyelések pontosságát ellenőrizzék. Az akcióról csak a légvédelmi tüzér alakulatok kaptak tájékoztatást, más szervet előzetesen nem értesítettek. A gyorsított ütemben felállított légvédelmi figyelőrendszer és a polgári ejtőernyős elhárító szolgálat kellő kiképzésben még nem részesült tagjai, több esetben nem észlelték az „ejtőernyőst”, vagy meglehetősen pontatlan jelentést küldtek róla a központi szerveknek. A figyelö szolgálat jobb felkészítése érdekében a későbbiekben több hasonló gyakorlatot is szerveztek. ${ }^{37}$

Az Erdély területén leszálló szovjet ejtőernyős csoportok hatékonyabb felszámolása érdekében a brassói román katonai parancsnokság 1941. VII. 14-én azzal a javaslattal fordult a sepsiszentgyörgyi magyar honvéd parancsnoksághoz, hogy létesítsenek közvetlen telefonkapcsolatot, és az ellenséges ejtőernyős bevetésekről ezen túl kölcsönösen tájékoztassák egymást. A rendkívül feszült magyarromán viszonyra való tekintettel ez meglehetősen szokatlan kezdeményezés volt. A sepsiszentgyörgyi magyar állomás-parancsnokság gyakorlati szempontból hasznosnak tartotta volna ezt a megoldást, és azt indítványozta, hogy szervezzék meg a kölcsönös információcserét mind a térségben müködő német, mind a román szervekkel. A IX. hadtest parancsoksága azonban saját hatáskörben nem vállalta a közvetlen katonai egyeztetéseket, hanem azt javasolta a brassói parancsnokságnak, hogy a román diplomácia ez ügyben hivatalos megkereséssel forduljon a magyar kormányhoz. ${ }^{38}$

Az együttmüködésnek gyakorlati szempontból valóban lett volna létjogosultsága, mert az erdélyi magyar-román határ térségében több ejtőernyős akcióra is sor került. 1941. VII. 19-én délután a VKF jelentést kapott a Központi Szállításvezetőségtöl, hogy a sepsiszentgyörgyi pályaudvar közelében ejtőernyős leszállást figyeltek meg. Jelentősebb honvédségi és csendőrségi erők bevetésével átkutatták a város körzetét, de nem találtak idegen személyeket. Azt valószínüsítették, hogy a leszállás a várostól 7 kilométerre húzódó határ közelében, vagy a határ túlsó oldalán román területen történt, és az ejtőernyősök Románia belseje felé haladtak tovább. ${ }^{39}$ A nap folyamán a Gyergyószentmiklóstól északra húzódó határszakaszon egy 8-10 fő körüli ejtőernyős csoport tüzharcba keveredett a román határvédelmi erőkkel. A 33. honvéd határvadász zászlóalj jelentette ezt a kolozsvári IX. hadtestnek és hozzátette, nem kizárható, hogy az ejtőernyősök egy része esetleg magyar területen bujkál. A hadtestparancsnokság ezért mozgósította a portyázó századokat, értesítette a besztercei honvéd állomás-parancsnokságot, és a körzetben lévő csendőr őrsöket. Fokozott figyelésre hívták fel az ejtőernyős elhárító szolgálat közegeit is. ${ }^{40}$

1941. VII. 24-én a pécsi IV. hadtest területén szerveztek ejtőernyős elhárító gyakorlatot. Reggel 8 órakor ejtőernyős szalmabábukat dobtak ki átrepülő magyar gépek. Fél órán belül 3 különbözö helyről érkezett bejelentés, hogy ejtőernyős leszállást észleltek. A somogyvári csendőr őrs tanúkihallgatása nyomán már az is tisztázódott, hogy magyar felségjelzésủ repülőgépek haladtak át. Tíz órakor újabb ejtőernyős bábut dobtak le, amelyről már 10 perccel később megérkezett az első bejelentés a katonai szervekhez. A gyors észlelés ellenére a gyakorlat számos tanulsággal szolgált. A lakossági bejelentés gyakran pontatlan volt, csak több egybehangzó információ esetén lehetett arra alapozni. A csendőrség jelentése általában pontosnak, körültekintőnek bizonyult. Fontos tapasztalat volt, hogy a megfigyelési adatokat egyaránt meg kell küldeni a járási katonai parancsnokságnak, hogy a helyi elhárítást szervezni, irányítani tudja, illetve a magasabb parancsnokságoknak, légvédelmi központoknak, mert azoknak van szélesebb áttekintése a körzetben zajló eseményekröl, és annak ismeretében tudnak intézkedni. Azt is megállapították, hogy nem szabad egy kis erejü ejtőernyős leszállás esetén az összes rendelkezésre álló erőt kirendelni, mert egy újabb bevetés elhárítására már nem maradnak alakulatok. ${ }^{41}$

Az ejtőernyősökkel kapcsolatos bejelentések sorában voltak olyan esetek, amelyeket több szavahihető szemtanú is megerősített, az elrendelt kutatás azonban semmiféle nyomát nem találta ellenséges katonák leszállásának. 1941. VII. 28-án és 29-én több információ is érkezett, hogy Kolozsvártól északkeletre, Apahida térségében ejtőernyősök szálltak le. Az egyik bejelentés a gyulai kórház arra utazó főorvosától, a másik egy katonai őrszemtől származott. A mozgósított honvédségi és csendőrségi erők több alkalommal is végigkutatták a jelzett területet, de nem találták nyomát ellenséges ejtöernyösöknek. ${ }^{42}$ Nem igazolódott az 1941. VIII. 4-ei, Galánta -Taksonyfalva térségéből jelentett ejtöernyős leszállás sem. Elöször egy 14 éves kislány tett bejelentést a föszolgabírói hivatalban egy 
nagyobb csoport ejtőernyős leszállásáról. Később egy polgárőr is jelezte a vágselyei csendőr őrsön, hogy a környéken idegen katonákat látott. A hírt a vágselyei állomásfőnök, a helyi csendőr örs és a járási főszolgabíró is, mint hitelesnek számító információt továbbította a felettes szerveknek. Az ejtőernyősök felkutatására indított akció azonban nem vezetett eredményre. Valójában azonban egyik esetben sem lehet kizárni, hogy történt ejtőernyős leszállás, de az ellenséges erők a földet érés után román, illetve szlovák területre távoztak. ${ }^{43}$

Az ejtőernyős elhárítás újabb sikeres alkalmazására szeptember első napjaiban került sor, a Miskolc térségében leszálló ejtőernyős csoport felszámolása során. 1941. IX. 2-án hajnali 4 órakor egy férfi lépett be a Miskolctól délre, 10 kilométerre fekvő Kistokaj vasúti megállójának forgalmi irodájába. Pisztolyt fogott a vasutasra és németül azt kérdezte, hol van, melyik országban, és milyen város van a közelben. A vasutas közölte, hogy Magyarországon van, Miskolc közelében. Erre a férfi magyar nyelvre váltott, átadta az ejtőernyőjét a vasutasnak, hogy tegye el „emlékbe”, de ne szóljon a hatóságoknak, mert visszajön és lelövi. Majd Miskolc felé indult, de csak lassan haladt, mert a leszállásnál megsérült a lába. ${ }^{44}$

Távozása után a vasutas azonnal telefonált a miskolci pályaudvar katonai parancsnokságára. Onnan motoros hajtányon katonai járőrt küldtek ki, amely Kistokajtól 1 kilométerre, egy kukoricatáblában elfogta az ejtőernyőst. ${ }^{45}$

A bevetés 1941. IX. 1-jén 21 órakor indult. A Kijev közeléből felszálló gépen 2 fős személyzet, 1 felkészítő politikai tiszt és két 4 fős szovjet ejtőernyős partizán csoport tartózkodott. A szovjet ejtőernyős partizán osztag Eperjes - Kisszeben - Rázlófalva (Raszlavica) térségébe igyekezett. Feladata a szlovák vasúti forgalom, az üzemanyag, hadianyag és lőszerszállítmányok megfigyelése, német állomáshelyek felderítése, frontra induló repülőről való jelentés küldése volt. A viharban a gép eltért a tervezett útiránytól, a politikai tiszt azonban 0.45-kor mégis kiugratta a csoportot, holott 110 kilométerre, délre jártak a tervezett területtől. A német papírok azonban arra utaltak, hogy a későbbiekben a Cseh-Morva Protektorátus területén kaptak volna új feladatot. Elsőként egy morva férfi ugrott a gépből, aki Miskolctól délre, 3 km-re, a vasút mellett ért földet, de nem nyílt ki az ejtőernyője, és szörnyethalt. Másodikként az osztag-parancsnok ugrott, aki Miskolctól délre, 2 kilométerre, szintén a budapesti vasút mellett szállt le, de megsérült a lába. A harmadik ugró egy ruszin férfi volt. Ö Görömböly közelében ereszkedett le, de fennakadt egy eperfán, belegabalyodott az ejtőernyő zsinórzatába és megfulladt. A csoport utolsó tagjaként a parancsnoka, egy cseh származású szakaszvezető ugrott. ${ }^{46}$

Az ejtőernyős leszállásról és a kihallgatás eredményéről értesülve a HM VI. (légoltalmi) csoportfőnöke a legszélesebb körü kutatásra adott utasítást, hiszen a magyar hadiipar egyik gócpontja kerülhetett veszélybe. A kereső akciót a VII. hadtest vezérkari főnöke személyesen irányította. A VII. (miskolci) csendőr kerület parancsnoka felhívta az alárendelt osztály- és szárny-parancsnokságokat, hogy a kutatás során a legkisebb részletre is kiterjedő alapossággal járjanak el. A miskolci és ózdi csendőr őrsöket kiemelt éberségre figyelmeztették, és az ejtőernyősök valószínűsíthető mozgási térségébe tartozó müködési területtel rendelkező csendőr őrsök osztály- és szárny-parancsnokságainak az alárendeltségébe tartozó többi őrs személyi állományából az ejtőernyős mozgás által valószínüsíthetően érintett őrsöket kirendelt személyzettel megerősítették. ${ }^{47}$

A szárny-parancsnokságok értesítették a járási katonai parancsnokságokat, valamint az illetékességi körükbe eső üzemi katonai parancsnokokat, hogy tegyék meg a szükséges intézkedéseket az esetleges szabotázsakciók kivédésére. A csendőrök az utakon mindenkit igazoltattak, minden járművet átkutattak, és ellenőrizték a vasúti forgalmat is. A mozgó járőrök nappal a félreeső helyeket vizsgálták át, a lakatlan épületeket, szalmakazlakat, kukoricásokat, az erdők peremét, éjszaka pedig az utakon és a vasútvonalak mentén járőröztek. A csendőrség felhívására a járási katonai parancsnokok utasították a települési vezetőket, hogy a helyi mütárgyakat polgári őrökkel őriztessék. Mozgósították a polgári ejtőernyős elhárítás erőket, és a községek bejáratánál, a vasútállomásokon ellenőrző pontokat állítottak fel. A településeken kidoboltatták, hogy minden gyanús személy felbukkanásáról, a magyarul nem tudókról, az ételt vagy felvilágosítást kérőkről a lakosság azonnal tájékoztassa a csendőrséget. ${ }^{48}$

1941. IX. 2-án Miskolcon és környékén, 1941. IX. 3-án az ózdi és putnoki járás területén tartottak nagy razziát a honvédség, a csendőrség, a rendőrség, az ejtőernyős elhárító szolgálat részvételével. 1941. IX. 3-án reggel Miskolc-Martintelep délkeleti szélén, a házaktól 200 méterre gallyakkal letakarva egy ejtőernyőt találtak, majd attól 150 méterre 2 kézigránátra bukkantak. Nem sokkal később Miskolctól északkeletre, 2 kilométerre, ütésálló csomagolásban egy ejtőernyőre függesztett rádió adóvevő került elő. A reggeli órákban munkába induló emberek találtak rá az út menti eperfán fennakadt 
ejtőernyős holttestére. Miskolctól délre a kutató alakulatok hamarosan megtalálták az elsőként kiugró ejtőernyős tetemét is. Ekkor már ismerték a még hiányzó 4. ejtőernyős személyleírását is, amit minden környező településen kidoboltattak. A csoport parancsnokának kézre kerítésére nagy erőket vetettek be. 1941. IX. 4-én a VII. csendőr kerület-parancsnoksága a sajószentpéteri és edelényi körzet átkutatására kirendelte a miskolci csendőr tanzászlóaljat. ${ }^{49}$

1941. IX. 4-én hajnalban — az előző nap az ózdi szárny-parancsnokságról azzal a céllal kirendelt csendőr alhadnagy, hogy Sajókaza térségében ellenőrizze a polgári őröket és maga is igazoltasson a Miskolc - Rimaszombat fóúton, a sajókazai vasútállomás közelében a fák között bujkáló alakot vett észre. Az illető menekülni próbált, de a csendőr elfogta. Kihallgatása során elismerte, hogy ejtőernyős partizán, aki 1941. IX. 2-án hajnalban ért földet Miskolc-Máriatelep közelében. Elrejtette az ejtőernyőjét és a nála lévő 2 kézigránátot, majd a határ felé indult. Amint megvirradt, behúzódott Görömböly-Újtelep egyik házának takarmányos csürjébe. A következő éjszaka visszatért Miskolcra, hogy inkább vasúton próbáljon a határra eljutni. Iratait és a pisztolyát elrejtette, csak 5000 korona és 150 német márka kézpénzt és egy tőrt tartott magánál. A következő napot a szirmabesnyői vasúti megálló közelében egy kukoricásban töltötte. Éjszaka felkapaszkodott egy tehervonatra, de Sajókazánál leszállt, mert nem volt biztos benne, hogy jó irányban halad. Ott fogták el. Két nap alatt 40 kilométert tett meg és már csak 50 kilométer volt hátra a szlovák határig. ${ }^{50}$

A szeptember eleji ejtőernyős leszállás hírét a hatóságok igyekeztek titokban tartani vagy elbagatellizálni. Egyrészt, hogy ne szolgáltassanak információkat az ejtőernyős csoport sorsáról a szovjet szerveknek. Másrészt, mert a hivatalos szervek attól tartottak, hogy az ország egyik nagyvárosának közvetlen veszélyeztetése bizonytalanságot, riadalmat, rémhíreket válthat ki a lakosság körében. Az ejtőernyős leszállás hírét 1941. IX. 5-én délben röviden közölte a rádió, és a Magyar Távirati Iroda (MTI) is kiadta a lapoknak, ezt követően azonban a sajtóellenőrzésben is résztvevő VKF utasítására figyelmeztették a szerkesztőségeket, hogy mellőzzék ezt a témát. Az Esti Kurír megpróbált cikket közölni az Északkelet-Magyarországon leszállt ejtőernyősökről, de a cenzúra kihúzta az írást. A VKF 2. osztálya közölte, hogy honvédelmi érdekből tilos híreket közölni az ejtőernyős bevetésekről. A közvélemény az eset részleteiről csak egy évvel később értesülhetett. A Csendőrségi Lapok 1942 októberében közreadta az ejtőernyőst elfogó csendőr beszámolóját, a miskolci ejtőernyős csoport felszámolásáról. Ezt átvéve1943. februárjában a Riadó címü folyóirat közölt hosszabb cikket az eseményekröl. ${ }^{51}$

1941 szeptember folyamán ismét számos olyan bejelentéssel kellett a hatóságoknak foglalkozniuk, amelyek utóbb tévesnek bizonyultak. 1941. IX. 4-én Mezőkomárom-Tóti puszta térségéből jelentettek ellenséges ejtőernyős leszállást Valójában attól valamelyest keletre, Dég határában Őztelek pusztánál a 3/1. bombázószázad egyik Börgöndről felszálló gépéből ugrott ki tisztázatlan okból a személyzet egyik tagja. A kiugró honvéd tizedes a földet éréskor életét vesztette. ${ }^{\mathbf{5 2}}$

1941 szeptember közepén német terület felől több, valószínűleg brit eredetü, gumírozott vászonból készült romboló és gyújtó léggömböt sodort a szél Magyarország fölé. Ez is növelte a téves lakossági bejelentések számát, mert a gyakorlatlan megfigyelő a távolból könnyen nézhette a katonai ballonokat lebegő ejtőernyősnek. Ez történt 1941. IX. 18-án, amikor Váctól 6 kilométerre, Kesd község határából érkezett bejelentés leszálló ejtőernyősről, és valószínűleg 1941. IX. 21-én is, amikor Győr közeében, Ménföcsanak, illetve Öttevény térségében láttak több ejtőernyőst lebegni az égen. A bejelentések nyomán a hatóságok kutatást indítottak és megerősítették a közúti és vasúti műtárgyak őrzését, de ellenséges ejtőernyősök nyomát nem látták, találtak viszont több katonai léggömböt. ${ }^{53}$

1941. IX. 27-én a BM szétküldte a rendőrkapitányságoknak az ejtőernyős bevetések tapasztalatait összegző tájékoztatót, melyet a VKF 2. osztálytól kapott. Eszerint, az ellenséges ejtőernyősök ledobására elsősorban éjszaka, gyakran rossz időjárási viszonyok mellett kerül sor. Mivel a magyar települések rosszul vannak elsötétítve, a gépek ez alapján tájékozódni tudnak. A csoportok létszáma általában 3 - 6 fö, minden tagnak külön feladata van. A személyi felszerelés része rendszerint 1 pisztoly, 2 kézigránát, 1 kés, tájoló, térkép, sebkötöző felszerelés, mintegy 1000 pengö értékü román, szlovák, német pénz, élelmiszerjegy, 2 - 3 hónapos vasúti jegy. Jól hamisított iratokkal rendelkeznek, bizonyos dokumentumokat rejtve, a ruhába bevarrva hordanak. A csoport rádió adóvevő készülékét ütésálló dobozban külön ejtőernyőn dobják le. A fő feladatuk a katonai felderítés, a szabotázs, ehhez igyekeznek felvenni a kapcsolatot kommunista, illetve zsidó személyekkel. ${ }^{54}$

A VKF kiemelte, hogy a jövőben számítani kell magyarok bevetésére is, mert ismertté vált, hogy több magyar állampolgár is részt vesz a partizánok felkészítésben. A ledobott csoportok nemzetközi 
összetételúek, és tevékenységük során gyakran átlépik a határokat. Az azonosításukhoz nem elegendő a róluk készült fénykép, ujjlenyomatot kell venni tölük. Elfogáskor alaposan meg kell motozni őket, nehogy megsemmisíthessék a náluk lévő bizonyítékokat. Az elfogásukat titokban kell tartani, nehogy az ellenség a hírekből szerezzen információkat a bevetett csoportok hollétéről, helyzetéről, tevékenységéröl. Rendkívül fontos a lakosság mozgósítása, hogy minden leszállást jelentsenek, és semmilyen támogatást ne nyújtsanak az ellenséges ejtőernyősöknek. ${ }^{55}$

A honvédelmi szervek az ejtőernyős elhárítás fejlesztése terén nemcsak a hazai tapasztalatokra támaszkodhattak. A szomszédos országokban, Romániában, Szlovákiában, Bulgáriában dolgozó diplomaták és katonai attasék részletes tájékoztatást küldtek haza az ottani eseményekröl is. 1941. IX. 30-án a szófiai magyar követ ilyen jellegü beszámolóját a Magyar Királyi Külügyminisztérium megküldte a belügyi tárcának is. A követ és meghatalmazott miniszter arról tájékoztatott, hogy szeptember közepén szovjet ejtőernyősök szálltak le a korábban Romániához tartozó Dél-Dobrudzsában, valamint a Balkán hegység keleti területein. A bevetett ejtőernyősök bolgárok voltak, többségük harcolt a spanyol polgárháborúban. Jól hamísított papírokkal rendelkeztek. Az elfogottak vallomása szerint rombolási feladattal kerültek bevetésre. ${ }^{\mathbf{5 6}}$

1941. IX. 30-án az I. légvédelmi hadtest összegezte a hadba lépés óta eltelt 3 hónap tanulságait a légvédelmi figyelő és jelentő szolgálat müködésével kapcsolatban. Megállapította, hogy a figyelö hálózat nem müködött kellő megbízhatósággal az ejtőernyős leszállások észlelése tekintetében. Ezért meghatározó fontosságú az örsök számának növelése, hogy a hálózat jobban le tudja fedni a leginkább veszélyeztetett keleti országrészeket. ${ }^{57}$

A lakosság fokozottabb bevonása érdekében, illetve hogy a téves bejelentések számát csökkentsék, 1941. X. 1-jén a Riadó címü lap hosszabb tájékoztató cikket közölt az ellenséges ejtőernyősökkel szembeni védekezés legfontosabb tudnivalóiról. Az írás kiemelte, hogy a bevetett diverzánsok fö feladata a felderítés, a rombolás, az erkölcsi fellazítás és lázítás, illetve az arra vállalkozók beszervezése partizánnak. Felsorolták azt is, milyen jelek kelthetik fel a lakosok figyelmét az esetleges ejtőernyős bevetésre. A nagyobb magasságban repülő magányos gép, a földön, elhagyott helyen friss ásás vagy taposás nyom, elhagyott katonai felszerelés, ejtőernyő vagy annak tartozékai, váratlanul felbukkanó, tájékozatlan idegen személyek, illetve rongálás, gyújtogatás, szabotázs bekövetkezése mind az ellenség jelenlétére utaló nyom lehet. ${ }^{58}$

Ennek mintegy igazolásaként szolgált, hogy 1941. X. 13-án éjszaka 23.30 körül a körösmezői vasútvonal 285 - 285,3 szelvénynél lévő vasúti híd ellen három fő robbantásos merényletet kísérelt meg. A VIII/1. honvéd őrszázad 13. sz. hídőrsége rálőtt a merénylőkre, akik erre visszavonultak az erdőbe. Az nem derült ki egyértelmüen, hogy egy korábban leszállt ejtőernyős csoport, vagy helyi kommunista ellenállók tettek-e kísérletet a híd felrobbantására. ${ }^{59}$

1941. X. 20-án a VKF arról intézkedett, hogy mielőbb fel kell állítani az északkeleti országrészbe tervezett 11 - 13. légvédelmi központokat. A gyors megvalósítás érdekében ezek ideiglenesen csökkentett létszámmal és kézi kapcsolású üzemmóddal fognak müködni, de 1942. III. 1-re bevethetőnek kell lenniük. ${ }^{60}$

A figyelőhálózat szervezeti és infrastrukturális fejlesztése mellett a VKF fellépett az ejtőernyős elhárító szolgálat müködése körül tapasztalható helyi visszásságok ellen is. A honvédelmi munkakötelezettség címén igénybe vett figyelőket, föként leventéket egyes helyeken 24 órás szolgálatra kötelezték, és a szolgálatért semmilyen ellátást vagy térítést sem kaptak. Gyakran a legnagyobb dologidőben rendelték ki őket szolgálatra, ami miatt nem tudtak segíteni a családi gazdaságban, vagy a napszámtól estek el. A behívott fogatokat egész nap üresen a lovakkal befogva várakoztatták. A VKF szerint legalább utólagos díjazást kell biztosítani a szolgálati napokra. Erre az „M” hitel keretében minden településnek megfelelő forrás áll rendelkezésére. Az igénybevételt csak indokolt esetben és az egyenlő terhelés elvén szabad elrendelni. A VKF felhívta a HM VI. csoportfönöksége figyelmét, hogy a problémák megoldására tegyen hathatós lépéseket. ${ }^{61}$

1941. október végére megszüntek a szórványos szovjet berepülések Magyarország légterébe. Ezért a VKF az önálló szervezetként felállított ejtőernyős elhárító szolgálat leszerelését javasolta. Az országos légvédelmi figyelö és jelentő hálózat őrsei azonban továbbra is folyatták az ejtőernyős megfigyelést. 1941. XI. 21-én a HM 35. osztálya elrendelte, hogy a légvédelmi figyelő és ejtőernyős elhárító szolgálatba a honvédelmi munkakötelezettség címén behívott polgári személyeket szereljék le, mert úgy ítélte meg, hogy a front eltávolodása és a kedvezőtlen téli időjárás miatt már nem áll fenn 
az ejtőernyős veszély. Egyben leszerelték a honi légoltalmi szolgálat még könnyített készültségben lévő egységeit is. ${ }^{62}$

A megnövekedett távolság és a kedvezőtlen időjárás azonban nem tartotta vissza a szovjet katonai szerveket, hogy újabb ejtőernyős csoportokat indítsanak Közép-Európa felé. 1941. XI. 24-én az Észak-Szlovákiában, az Árvanádas-i (Trsztena-i) járásban, Námesztótól (Namesztó) északra, Zubrohlava község határában egy szovjet szállítógép 10 ejtőernyőst dobott le. A szlovák karhatalmi szervek 1 partizánt lelőttek, 1 főt elfogtak. A lelőtt személy besztercebányai illetőségü volt. Két útlevelet, nagyobb mennyiségü szlovák és magyar pénzt, illetve USA dollárt találtak nála. A magyar pénz alapján azt feltételezték, hogy magyar területen is lehettek feladatai a csoportnak, ezért értesítették a magyar hatóságokat. Arról azonban a magyar szervek csak hónapok múlva szereztek tudomást, hogy szovjet részről november második felében Magyarország ellen is terveztek ejtőernyős akciót, amit azonban különböző okok miatt végül 1942 januárjára halasztottak. ${ }^{63}$

\section{A BORKANYUK szovjet ejtőernyős partizánosztag bevetése és felszámolása}

Az első, Magyarország területén végrehajtandó feladattal megbízott ejtőernyős szovjet partizánosztag 1942. I. 4-én került bevetésre, BORKANYUK Alekszej vezetésével. ${ }^{64}$ A csoport felkészítése még 1941 szeptemberében kezdődött. A Moszkva melletti Szhodnyában múködött az a bázis, ahol a román, bolgár, finn, német, cseh kommunisták mellett magyarokat is kiképeztek a partizánharcra. Miután a felkészítés befejeződött, 1941. IX. 24-én búcsúvacsorát tartottak, amelyen megjelent ROSENFELD (RÁKOSI) Mátyás is. A csoportot ezután a Krím-félszigetre, Szimferopolba szállították. Innen a Fekete-tenger keleti partvidékére Anapába kerültek, ahol más partizán csoportokkal együtt a bevetést várták. 1941. IX. 10. és 1941. X. 12. között innen indítottak útnak hat ejtőernyős osztagot bolgár területre, és 1941 szeptember-október folyamán két csoportot román területre. 1941 október végén a német előrenyomulás miatt a partizánbázist áthelyezték a Novorosszijszk melletti Gelendzsikbe (Gilicsin). ${ }^{65}$

A csoport azt a feladatot kapta, hogy gyüjtsön felderítési adatokat a Körösmező térségében zajló közúti és vasúti forgalomról, a magyar csapatok mozgásáról, egyes fontos személyek megjelenéséről. Rongálja meg a körösmezői vasútvonalat, hajtson végre robbantást a nagybocskói vegyészeti gyárban, gyújtsa fel a központi fatelepet, rombolja a körzetben lévő közlekedési mútárgyakat. Keressen kapcsolatot a helyi kommunistákkal, ruszin ellenállókkal és szervezze be őket diverzáns akciók végrehajtására. Keltsen bizonytalanságot, szítson elégedetlenséget, terjesszen rémhíreket a lakosság körében. Az eredeti tervek szerint a szovjet ejtőernyős partizán osztagot egy másik hat fős osztaggal együtt vetették volna be. Az 1941 november végi akció a rendkívül rossz időjárás miatt elmaradt. 1942 január elején a közös bevetéshez nem állt rendelkezésre nagyobb befogadóképességü repülőgép, ezért azt tervezték, hogy a két csoportot egymást követő éjszaka indítják. ${ }^{66}$

1942. I. 3-án este a Szolnce Dar-i vízi repülőbázisról a csoport 6 tagjával szállt fel egy repülőcsónak, hogy Kárpátaljára vigye őket. A partizánok géppisztolyt, pisztolyt, 2-2 kézigránátot vittek magukkal, 3 nagyobb ejtőernyős csomagban pedig további 50 kézigránátot, 10 kész pokolgépet, összesen mintegy $100 \mathrm{~kg}$ robbanóanyagot, gyutacsokat, illetve nagyobb mennyiségü élelmiszert rakodtak fel a gépre. 1942. I. 4-én hajnali 1 órakor érték el a célterületet $2500 \mathrm{~m}$ magasságban. Az első három fö kiugrása után leoldották a gép szárnyaira erősített 3 nagyobb csomagot, melyekben egyenként $30 \mathrm{~kg}$ robbanóanyag, gyutacsok, fegyverek, lőszer és élelmiszer volt. A repülőgép kört írt le, majd ugrott a következő három fö A bevetést holdtölte idején hajtották végre, de a Kárpátok felett rendkívül kedvezőtlen volt az időjárás, felhős éggel, erős széllel. A kiugrás a magyar-német határ térségében történt, a csoport egy része német területen ért földet. A szétszóródó ejtőernyősök nem találták meg egymást, a magas hó és a nagy hideg nagyon megnehezítette a mozgásukat. ${ }^{67 . ;}$

1942. I. 4-én délelőtt a Körösmezőtől északra, 5 kilométerre lévő stebnai gátőrház közelében a gátőr egy ejtőernyőt talált, amelyre egy bádogtartály volt erősítve. Bejelentése után a 3 . határvadász zászlóalj közeli, 4. számú őrse 3 fős mozgójárőrt küldött a helyszínre. A járőr, a bázistól 400 méterre az erdőben egy szürke ruhás egyénbe botlott, aki géppisztollyal azonnal tüzet nyitott. Két katona a vállán megsebesült, az ismeretlen férfi elmenekült. A tủzharc nyomán a 3. határvadász zászlóalj teljes állományát riadóztatták. Értesítették a közelben állomásozó katonai alakulatokat, a csendőrséget és a polgári karhatalmi erőket. A járási katonai parancsnok elrendelte, hogy az ejtőernyős elhárító szolgálat és az erdészet alkalmazottai, a csendőrség közremüködésével fésüljék át a feltételezett leszállás helyét, a Mohelki, Kozmielcsek és Tiszaborkút községtől északra elterülő erdőséget. ${ }^{68}$ 
1942. I. 5-én a 3/2. és 3/3. határvadász század végigkutatta az ejtőernyő megtalálásának és az előző napi tűzharcnak a körzetét, és 11 órakor rábukkantak az egyik ejtőernyősre, akit a kifejlődő tüzharcban lelőttek. Az ejtőernyős overállt viselt, alatta katonai egyenruhát, tiszti rendfokozattal. Mivel a leszállás a határ közelében történt magyar szervek értesítették a galíciai oldalon lévő német szerveket. A németek már tudtak a bevetésről, mert a reggeli órákban ott is találtak egy ejtőernyőt. Az elrendelt keresés során, 17 órakor Worochta és Tatarov között a németek elfogtak egy ejtőernyőst, akit a tatarovi német parancsnokságról átkísértek a körösmezői pályaudvar-parancsnokságra, hogy ellenőrizzék a nála lévő iratok adatait. Budapestről kapott tájékoztatás nyomán kiderült, hogy azok hamisak, így az ejtőernyős német ôrizet alatt maradt, ahol néhány nappal később elhalálozott. ${ }^{6}$

1942. I. 6-án újabb nagyszabású kutatást indítottak az ejtőernyősök elfogására. Német oldalon 260 katonát irányítottak a térségbe. Magyar részről a 3. határvadász zászlóalj és a III/1-3. erődszázad katonái alaposan átfésülték a leszállás szélesebb körzetét. Megerősítették a körösmezői vasútvonal és az ott lévő mütárgyak védelmét, folyamatos járőrözést folytattak a közutakon és a vasút mentén, mindenkit igazoltattak. Örizetbe vettek több, már korábban is megfigyelt, felforgatással gyanúsított baloldali lakost, illetve a személyazonosságát, vagy ott tartózkodásának okát igazolni nem tudó idegent. Hirdetmények kiragasztásával és doboltatással tájékoztatták az embereket, hogy müködjenek együtt a hatóságokkal, jelentsenek minden gyanús körülményt, a partizánokkal kapcsolatos nyomra vezetésért 1000 pengö jutalmat ígértek. ${ }^{70}$

1942. VI. 6-án délután egy helyi lakos bejelentette, hogy két partizánt látott az 1008. magassági pont közelében a hátáron átjönni német területről. A kiküldött járőr megjelenésekor a partizánok ismét átlépték a határt. Egyikük elmenekült, a másikat a német katonaság elfogta és Sztaniszlauba szállította, ahol az ottani német biztonsági szervek is kihallgatták, mert egy nagyobb szabású partizánakció veszélyére gyanakodtak. A kihallgatási jegyzökönyvet megküldték a magyar hatóságoknak is. Magyar részről azonban kikérték a foglyot, hogy további részletekről kérdezzék ki. Átadása után Budapestre szállították és az éppen folyamatban lévő ScHÖNREZ Zoltán elleni per kapcsán igyekeztek információkhoz jutni tőle. Kihallgatása után visszaadták német őrizetbe. ${ }^{71}$

1942. I. 8-án a németek elfogták az ejtőernyős csoport rádiósát. A leszállás után magára maradt ejtőernyős elásta a rádiót. Először egy üres kunyhóban bújt meg Worochta mellett, majd napokon át bolyongott a hegyekben, miközben átlépte a határt. Amikor a területet átfésülő német határvadászok a közelébe értek, ellenállás nélkül megadta magát. Másnap lakossági bejelentés érkezett a 3 . határvadász zászlóaljhoz, hogy egy idegent láttak a hegyekben, a leszállás körzetében, aki bekopogtatott több házba, segítséget és szállást kért, de mivel nem kapott, elhagyott pajtákban húzta meg magát. Az illető felkutatására a 3/4. határvadász őrs irányításával kivonult az ejtőernyős elhárító szolgálat. Az előző napok tapasztalatai alapján, hogy a partizán ne tudjon átszökni a határon, a másik oldalán akcióba lépett a német katonaság is. 1942. I. 10-én hajnali 2 órakor a magyar karhatalmi erők rátaláltak az ejtőernyősre, aki rálőtt a kereső csapatokra, majd német területre menekült. Itt azonban a reggel folyamán a német erők bekerítették, és tüzharcban lelőtték. ${ }^{72}$

Az ejtőernyős csoport parancsnoka a leszállás után Körösmezőre ment. Az elözetes megbeszélés szerint az egész csoportnak ott kellett volna találkoznia, megfelelő helyismeret hiányában azonban a szétszóródó csoport többi tagja nem talált oda. A csoportparancsnok a testvérbátyja özvegyéhez kopogott be, ahol befogadták, és a másik testvére segítségével bújtatták. A hatóságok átfogó razziákat tartottak a körzetben, folytatták a kommunista gyanús személyek és szimpatizánsok letartóztatását, akikről feltételezték, hogy segítséget nyújtanának a partizánoknak. Ennek során, 1942. II. 9-én őrizetbe vették a szovjet ejtőernyős partizán osztag parancsnokát is. Ellenőrzése és kihallgatása nyomán 1942. II. 12-én a rokonainál elfogták az utolsó ejtőernyőst is. Letartóztatása után Budapestre szállították. Perére 1942. IX. 25-én került sor. A magyar állam elleni fegyveres szervezkedés és az ellenséggel való együttmüködés alapján halálra ítélték, és 1942. X. 3-án kivégezték. ${ }^{73}$

Az elfogott partizánok kihallgatása során kiderült, hogy a második ejtőernyős csoportot 1942. I. 28. és 1942. II. 10. között tervezték indítani ugyanabba a körzetbe. Ezek alapján a VIII. hadtest tájékoztatta az adott térségben állomásozó katonai egységeket a várható újabb partizán bevetésröl. Azt is megtudták a hatóságok, hogy a ledobott ejtőernyősöknek az utasításaik szerint egy ideig csak rejtőzködni és tájékozódni kellett, csak a második csoport megérkezése után kezdték volna meg a diverziós tevékenységet. A második csoport bevetése azonban elmaradt. Az első csoport bevetése után a viszszatérő gép eljegesedett, és a török partok közelében lezuhant. A hat főnyi személyzet, valamint a csoportokat felkészítő és a bevetést irányító politikai tiszt is életét vesztette. Mivel az első csoportjától 
nem érkezett semmiféle rádióüzenet, ́́gy a második csoport bevetését lefújták. Az osztag tagjai 1942 áprilisban átkerültek a krasznodári partizániskolába, majd májusban visszavitték őket Szhodnyára. Itt az osztagot feloszlatták, a tagok más feladatokat kaptak. ${ }^{74}$

A VKF 2. osztálya - 1942 elején Kárpátalja térségében ledobott szovjet ejtőernyős partizán osztag bevetésének tanulságait levonva - a belügyminiszterhez fordult. Közölte, hogy az ejtőernyős elhárítás eddig sikeresen teljesítette a feladatait, a ledobott ejtőernyős csoportokat felfedezték és felszámolták vagy kiszorították az ország területéről. Az 1942. I. 4-ei eset azonban arra hívta fel a figyelmet, hogy újabb bevetések várhatók, mely során a partizánok igyekeznek lakatlan területen földet érni, egy ideig rejtőzködnek és próbálnak kapcsolatokat kiépíteni a lakossággal. Ezért a VKF azt kérte a belügyi szervektöl, hogy tartsanak gyakoribb és szigorúbb idegenrendészeti ellenőrzéseket, a veszélyeztetett területeken sürübben szervezzenek razziákat. A lakatlan területeket is időnként vizsgálják át, esetleg rendőrkutyák felhasználásával. A hadiüzemek, fontosabb létesítmények körzetében fokozottabb megfigyelést végezzenek, a készülő nagyfontosságú közéleti események, például Joachim von RIBBENTROP német külügyminiszter magyarországi látogatásának részleteiről csak az utolsó pillanatban tájékoztassák a nyilvánosságot. Az ejtőernyősökre vonatkozó híreket ne közölje a sajtó, ha sikerült őket elfogni, azt sem, mert ez csak felesleges izgalmat vált ki az emberek körében, az ellenség pedig jól tud tájékozódni, hogy mi a helyzet a bevetett partizánokkal. ${ }^{75}$

Az újságok és szakmai folyóiratok az általános tapasztalatok és tanulságok oldaláról foglalkoztak az ejtőernyős bevetésekkel, anélkül, hogy a konkrét eseményeket ismertették volna. A Csendőrségi Lapok 1942. II. 1-jei száma arról írt, hogyan kell eljárni ellenséges repülőszemélyzet ejtőernyős leszállása esetén. A cikket nyilvánvalóan a januári partizánbevetés indokolta, de annak részleteit nem adta közre. Egy hónap múlva a lap újabb írást közölt, melyben a diverzáns csoportok feladatait és bevetésük sajátosságait ismertették. Emlékeztetett arra, hogy a Szovjetunióban nagy súlyt helyeztek az ejtőernyős harcmodorra, és nagy számban képeztek ki partizán csoportokat. Megállapította, hogy az eddigi szórványos bevetések nem jártak sikerrel, de továbbra is várható ilyen támadás. Hangsúlyozta az írás, hogy az ejtőernyősök felderítése és leküzdése elsősorban a rendvédelmi szervek, főként a csendőrség feladata, de komoly szerepe lehet a polgári lakosságnak is. ${ }^{76}$

1942 március folyamán nagyobb számban érkeztek Németország ellen bevetett brit romboló és gyújtó léggömbök a magyar légtérbe is. Egyedül 1942. III. 22-én 52 ballon átrepülését észlelték. Ennek nyomán ismét megszaporodtak az ejtőernyős leszállással kapcsolatos lakossági bejelentések, mert a léggömböket sokan ernyőkupolának nézték. ${ }^{77}$

1942. IV. 1-jén a HM VI. csoportfönök kezdeményezésére szakmai értekezletre került sor, melyen megbeszélték a légvédelmi figyelő és jelentő hálózat helyzetét, fejlesztésének preferenciáit. Megállapították, hogy az északkeleti országrésznek, Kárpátaljának és Észak-Erdélynek kell elsőséget biztosítani. Ezt követi a dunántúli olajvidék védelmét szolgáló délvidéki és muraközi területek fejlesztése, a Tiszántúl és a Duna-Tisza köze figyelőhálózatának sürítése viszont 1943-ra marad. Az északkeleti területeken kézi kapcsolású üzemmódban és csökkentett létszámú őrsökkel már müködött a 9. munkácsi és a 10. máramarosszigeti légvédelmi központ mellett a 11. zilahi és a 12. szászrégeni központ is. A munkácsi központ automatizálását és a 13. csíkszeredai felállítását pedig 1942 nyarára tervezték. ${ }^{78}$

Az ejtőernyős elhárítás nagy fontosságára való tekintettel, a nemzetközi információk és a magyarországi tapasztalatok alapján a budapesti I. honvéd hadtest egy hosszabb, 50 oldalas szabályzatot adott ki az Ejtőernyős elhárítás (ejel.) szabályozása címmel a hadtest területére. Ez tartalmazta az elhárítás elveit, az ejtőernyős partizánok bevetésének célját és alkalmazásuk sajátosságait, az ejtőernyős figyelő és elhárító szolgálat felépítését és föbb feladatköreit. Az I. hadtest területén 13. elhárító körzetet alakítottak ki. A honvédelmi és rendvédelmi szerveken kívül az I. hadtest területén az ejtóernyős elhárításba mintegy 2550 fő polgári karhatalom bevonását tervezték. ${ }^{79}$

Az I. honvéd hadtest által kidolgozott anyag alapján a HM 1942. IV. 4-én országos szabályozást adott ki az ejtőernyős elhárításra vonatkozóan. Ebben rögzítették, hogy teljes mozgósítás esetén az ejtőernyős elhárító szolgálat automatikusan életbe lép az ország egész területére vonatkozóan, a határvédelmi készültség, részleges mozgósítás, vagy honi légvédelmi készültség esetén pedig az érintett területeken. Az ejtőernyős elhárítás szervezője és békeidőben irányítója a HM 35. osztálya, háborúban pedig az országos katonai föparancsnok, aki e feladat tekintetében a Fővezérségnek volt alárendelve. Az egyes hadtestek területét ejtőernyős elhárító körzetekre kellett osztani, ezek parancsnokai voltak illetékesek a területükön az egységes vezetésre. Lehetőleg minden településen saját elhárító osztagot 
kellett felállítani. A különböző őrségek, hadiüzemi katonai parancsnokok és a községi elhárító szervek tevékenységét a körzeti katonai parancsnoknak alárendelt járási levente parancsnok koordinálta. ${ }^{\mathbf{8 0}}$

Az ejtőernyős elhárító szolgálatot a Magyar Királyi Honvédség, a Magyar Királyi Csendőrség, a Magyar Királyi Rendőrség és a Magyar Királyi Pénzügyőrség közegei látták el. Szükség esetén polgári személyek is bevonásra kerülhettek, különleges légvédelmi szolgálat címén. Elsősorban tüzharcosok, polgári lövészek, a legidősebb levente évfolyam, tagjaira, illetve egyéb megbízható keresztény magyar állampolgárokra kellett építeni. Belölük figyelö és fegyveres elhárító egységeket lehetett szervezni. Üzemi munkás fegyveres egységbe nem volt beosztható, csak figyelő szolgálatba. A fegyveres elhárító szolgálat tagjai katonasapkát és nemzeti színű karszalagot kaptak. Fegyvert önvédelem címén használhatták. A fegyveres egységek kirendeléséröl a körzeti parancsnok döntött, vagy valamelyik felettes szerve. Közvetlen ejtőernyős támadás esetén azonban a legalacsonyabb rangú helyi parancsnok is elrendelhetett a bevetést. ${ }^{81}$

Az ejtőernyős figyelést elsősorban a honi légvédelmi figyelő és jelentő szolgálat, a különböző katonai őrségek és őralakulatok, a Magyar Királyi Csendőrség, Magyar Királyi Rendőrség és Magyar Királyi Pénzügyőrség közegei végezték. A feladatba be kellett vonni a települések polgári légoltalmi figyelő és riasztó szolgálatát, a külön ejtőernyős figyelésre felállított őröket, a tüzoltószerveket, a MÁV légvédelmi figyelőszolgálatát, az üzemi őrségeket, portásokat, gondnokokat, a polgári közbiztonsági szervezetek tagjait, polgárőröket, a külterületen dolgozó, többségükben fegyverrel ellátott közhatósági jogú személyeket és települési alkalmazottakat, mezö-, erdő-, hegy- és halöröket, gát-, zsilip- és csatornaőröket, csőszöket, útkarbantartókat. A figyelöszolgálat 24 órán át müködik. ${ }^{\mathbf{2}}$

Minden megfigyelést haladéktalanul jelenteni kellett a honvédségnek, vagy a csendőrségnek, illetve a rendőrségnek. Minden állami, vasúti vagy magántávbeszélő készüléken az „ejtőernyős beszélgetés" jelszó bemondásával kezdeményezett hívás a kapcsolásnál elsőbbséget élvezett. A bejelentésnél közölni kellett a nevet, címet, foglalkozást, illetve az ejtőernyősök megjelenésének helyét, idejét és létszámát. A befutó jelentést a honvéd, csendőr, rendőr szervek a saját hatáskörben elrendelt intézkedés mellett a kerületi légvédelmi központnak és az illetékes hadtest-parancsnokságnak is továbbították. A helyi légvédelmi központ értesítette az Országos Légvédelmi Központot, a hadtestek pedig tájékoztatták a VKF 1. és a HM 35. osztályát. ${ }^{83}$

A Szovjetunióval a hadiállapot beállta után az első 7 hónapban, 1942 elejéig összesen 45 alkalommal riasztották az ejtőernyős elhárító szerveket. Ez idő alatt 4-5 feltételezett és három beigazolódott ellenséges leszállásra került sor Magyarországon. A feltételezett esetek a magyar-német és magyar-román határ mentén történtek, ha a partizánok magyar területen értek is földet, a leszállás után valószínüleg azonnal elhagyták az országot. A másik három akció közül két alkalommal téves ledobás történt, 1941. VII. 8-án Románia, 1941. IX. 2-án Szlovákia helyett értek földet ejtőernyősök magyar felségterületen, csak az 1942. I. 4-i bevetés irányult ténylegesen Magyarország ellen. A három földre szállt csoportot a magyar katonai, rendvédelmi és polgári ejtőernyős elhárító szervek gyorsan felszámolták. A ledobott 16 partizán közül nyolc föt elfogtak, nyolc fö az ugrás, illetve a fegyveres harc során életét vesztette. 1942 folyamán újabb ejtőernyős partizánok már nem érkeztek Magyarországra. A következő akciókra majd csak 1943 nyarán került sor. A hatékony magyarországi elhárítás miatt június-július folyamán két új csoportot a kevésbé ellenőrzött Dél-Lengyelországban dobtak le, hogy onnan jussanak el magyar területre. Mindkét osztagot gyorsan felszámolták. ${ }^{84}$

A magyar hadba lépést követően a katonai vezetés a rendvédelmi szervekkel közösen gyorsan és hatékonyan intézkedett, az ország területén leszálló várható szovjet ejtőernyős partizán osztagok felderítésére és felszámolására. A honvédség központi szabályozása és egységes irányítása mellett, az operatív feladatokat elsősorban a csendőrség látta el, az ejtőernyős elhárító szolgálatba bevont polgári karhatalom közremüködésével. Az ejtőernyős bevetések elleni fellépés szempontjából fontos intézményrendszer, infrastruktúra, megfigyelő és híradóeszközök terén jelentős hiányok mutatkoztak, a magyar területre érkező ellenséges osztagokat a háború első két évében sikerült semlegesíteni. 


\section{Jegyzetek:}

${ }^{1}$ GAZSI: Ejtőernyős partizántevékenység és elhárítás Magyarországon 1941-ben.513.p. ; Ejtőernyős elháritás. 4.p.

${ }^{2}$ A Magyar Királyi Honvédelmi Minisztérium (HM) VI. csoportfönökségének 35. (légoltalmi) osztályát az ejtőernyős elhárítás hatásköre szervezeti hovatartozásának az eldöntésekor FóNAGY János alezredes vezette.

HIM.HL. VKF.Eln. 1. 5522/1941., 6968/1941.

${ }^{3}$ Loc.cit.

${ }^{4}$ A Magyar Királyi Honvédelmi Minisztérium VI. föcsoportfőnökségének a vezetője az ejtőernyős elhárítás hatásköre szervezeti hovatartozásának az eldöntésekor JUSTY Emil tábornok volt (1941. VII. 29-től vezérőrnagy).

HIM.HL. HM.Eln. I. 42 107/1941. ; HIM.HL. VKF op.cit. Eln. Hdm. 554/1941.

${ }^{5}$ Loc.cit.

${ }^{6}$ HIM.HL. HM.Eln. op.cit. 35. 135 010/1942. ; PATAKY - ROZSOS - SÁRHIDAI: I.köt. 59.p.

${ }^{7}$ HIM.HL. VKF op.cit. Eln. 1. 6341/1941. + 6948/1941. ; HIM.HL. TGY 2974. V. rész 556.p., VI. rész 661.p.

${ }^{8}$ 1939/II.tc. ; Ejtöernyös elhárítás. op.cit. 11-16.p.

${ }^{9}$ HIM.HL. HM.Eln. op.cit. 20. 99 861/1941.

${ }^{10}$ HIM.HL. VKF op.cit. Eln. 1. 6537/1941 ; GAZSI: Ejtőernyős partizántevékenység és elhárítás Magyarországon 1941ben. op.cit. 515.p.

${ }^{11}$ Ejtöernyös elháritás. op.cit. 11-20.p.

12194 700/1941. (VII. 11.) BM.r. ; Örzik a lábon álló termést. ; A magyar légoltalom hírei. 230.p.

${ }^{13}$ A IV. hadtest területéhez tartozó Tabi járás katonai parancsnoka 30 község ejtőernyős elhárító osztaga számára 1165 puska és 12 golyószóró kiutalását kérte.

HIM.HL VKF op.cit. Eln. 5. 357/M/1941. ; HIM.HL 10. gy.dd. 237/M/1941., 249/M/1941., 253/M/1941.

${ }^{14}$ A javaslat előterjesztője BÁTKY József csendőr ezredes, a miskolci székhelyü VII. csendőr kerület-parancsnok volt. HIM.HL HM.Eln. op.cit. 20. 99 861/1941.

${ }^{15}$ Fel kell készülni orosz ejtőernyős támadásra. 2.p. ; Hogyan küzdjük le az ellenség ejtőernyőseit. 7.p.

${ }^{16}$ MNL OL K-149. BM VII. Res. 1941-14-11 396.

${ }^{17}$ HIM.HL VKF op.cit. Eln. 1. Napi helyzetjelentések 1941. június 28.

${ }^{18 . H I M . H L . ~ T G Y ~ o p . c i t . ~ 2723 . ~ 20 . p . ~}$

${ }^{19}$ Loc.cit. 2787. V. rész 257.p. ; GAzSI: Ejtőernyős partizántevékenység és elhárítás Magyarországon 1941-ben.

${ }^{20}$ HIM.HL. VKF op.cit. Eln. sz.n. 1941. június 29.

${ }^{21}$ HIM.HL. VKF op.cit. Eln. 1. Napi helyzetjelentések 1941. június 29., június 30. ； KUN: 137.p.

${ }^{22}$ GAZsI: Ejtőernyős partizántevékenység és elhárítás Magyarországon 1941-ben.op.cit. 506.p.

${ }^{23}$ A Kassa-i VIII. csendőr kerület parancsnoka ekkor TöLGYESY Győző csendőr ezredes volt. REKTOR: 217.p.

${ }^{24}$ HIM.HL. HM.Eln. op.cit. 20. 99 959/1941. ; HIM.HL. VKF op.cit. Eln. 1. Napi helyzetjelentések 1941. július 2.

${ }^{25}$ HIM.HL. VKF op.cit. Eln. 1. 1289/M/1941. ; HARSÁNYI: 79.p. ; PARÁDI: A magyar Királyi Csendörség. Az első magyar polgári, központositott közbiztonsági örtestület 1881-1945. 116-117.p.

${ }^{26}$ HIM.HL. VKF op.cit. Eln. 1. Napi helyzetjelentések 1941. július 2. ; HIM.HL. TGY op.cit. 2787. V. rész 262.p.

${ }^{27}$ GAZSI: Ejtőernyős partizántevékenység és elháritás Magyarországon 1941-ben. op.cit. 508.p.

${ }^{28}$ HIM.HL. VKF op.cit. Eln. 1. Napi helyzetjelentések 1941. július 6.

${ }^{29}$ MNL.OL. K-149. op.cit. BM VI/b. Res 1942-4-9607. 3701/1941. ; PATAKY - ROZSOS - SÁRHIDAI: op.cit. 77.p.

${ }^{30}$ GAZSI: Ejtőernyős partizántevékenység és elhárítás Magyarországon 1941-ben.op.cit. 508-509.p.

${ }^{31}$ HIM.HL. VKF. op.cit. Eln. 1. Napi helyzetjelentések 1941. július 14.

${ }^{32}$ GAZsI: Ejtőernyős partizántevékenység és elhárítás Magyarországon 1941-ben.op.cit. 509-510.p.

${ }^{33}$ HIM.HL. VKF. op.cit. Eln. 2. 45 861/1941. ; HIM.HL. VKF. op.cit. Eln. 1. Napi helyzetjelentések 1941. július 18.

${ }^{34}$ MNL.OL. K-149. BM VI/b. Res. 1942-4-9607. 3701/1941.

${ }^{35}$ HIM.HL. HM.Eln. op.cit. 10. 48 961/1941. ; MNL.OL. K-428 MTI Kőnyomatos. Napi Hírek 1941. július 10. 34.p.

${ }^{36}$ Ejtöernyös elhárítás. 16-19.p.

${ }^{37}$ HIM.HL. VKF. op.cit. Eln. 1. Napi helyzetjelentések 1941. július 12.

${ }^{38}$ GAZSI: Ejtőernyős partizántevékenység és elhárítás Magyarországon 1941-ben.op.cit. 517-518.p.

${ }^{39}$ HIM.HL. VKF. op.cit. Eln. 1. Napi helyzetjelentések 1941. július 19.

${ }^{40}$ GAZSI: Ejtőernyős partizántevékenység és elhárítás Magyarországon 1941-ben.op.cit. 510-511.p.

${ }^{41}$ HIM.HL. 10. gy.dd. op.cit. 249/M/1941.

${ }^{42}$ HIM.HL. VKF. op.cit. Eln. 1. Napi helyzetjelentések 1941. július 29.

${ }^{43}$ MNL.OL. K-149. op.cit. BM VII. Res. 1942-4-9607. 13 021/1941., 13 212/1941.

${ }^{44}$ GAZSI: Ejtőernyős partizántevékenység és elhárítás Magyarországon 1941-ben. 502-503.p.

${ }^{45}$ A VII. hadtest parancsnokságán lefolytatott kihallgatás során kiderült, hogy ANDRASCSIK Stefánnak hívják, szlovák származású, kisszebeni illetöségü. 1939 tavaszán a csehszlovák haderő kassai tüzérezredében szolgált, szakaszvezetőként. Csehszlovákia szétesése után Lengyelországba ment, és Krakkóban beállt a PRAHALA tábornok által alakított csehszlovák alakulatba, amely a német-lengyel háború végén a 
Szovjetunióba evakuált. Felszereléséhez egy Mauser-pisztoly, 2 kézigránát, 2 robbanógyutacs, 1 rohamkés, 5000 szlovák korona, cseh papírok, Németországba szóló útlevél, német kenyér és vaj jegy, illetve civil ruha tartozott

FERENCZI: 609-610.p.

${ }^{46}$ HIM.HL. VKF. op.cit. Eln. 1. 6140/1941. ; MNL.OL. K-149. op.cit. BM VII. Res. 1942-4-9607. 14 102/1941.

${ }^{47}$ A HM VI. (légoltami) csoport fönöke JuSTY Emil vezérőrnagy, a VII. hadtest vezérkari főnöke pedig KozMA István vezérkari ezredes volt.

MNL.OL. K-149. op.cit. BM VII. Res. 1942-4-9607. 14 120/1941.

${ }^{48}$ FERENCZI: op.cit. 610.p.

${ }^{49}$ HIM.HL. VKF. op.cit. Eln. 1. 6140/1941.

${ }^{50}$ FERENCZI: op.cit. 610-611.p.

${ }^{51}$ MNL.OL. K-428. MTI Kőnyomatos. 495. köt. 1941. szeptember 5. ; MÁRKUS - SzINAI-VÁSÁRHELYi: 156.p. ;

SALY: 390-391.p.

${ }^{52}$ HIM.HL. 10.gy.dd. 237/M/1941.

${ }^{53}$ MNL.OL. K-149. op.cit. BM VII. res. 1942-4-9607. 15 048/1941., 16 049/1941.

${ }^{54}$ HIM.HL. VKF op.cit. Eln. 2. 47 653/1941.

${ }^{55}$ MNL.OL. K-149. op.cit. BM VII. res. 1942-4-9607. 14 900/1941.

${ }^{56}$ Loc.cit. BM VII. res. 1942-4-9607. 15 852/1941.

${ }^{57}$ HIM.HL. VKF op.cit. Eln. 1. 6968/1941.

${ }^{58}$ Hogyan kell védekezni ejtőernyősök ellen?

${ }^{59}$ HIM-HL. VKF op.cit. Eln. 1. Napi helyzetjelentések 1941. október 13.

${ }^{60}$ A 11-13. légvédelmi központok székhelyei voltak: 11. Zilah, 12. Szászrégen, 13. Csíkszereda.

HIM.HL. VKF op.cit. Eln. 1. 6524/1941.; 4117/1942.

${ }^{61}$ Loc.cit. Eln. 1. 6537/1941.

${ }^{62}$ Loc.cit. Eln. 1. 6558/1941., 6743/1941.

${ }^{63}$ GAzsI: Ejtőernyős partizántevékenység és elhárítás Magyarországon 1941-ben. 518.p.

${ }^{64}$ A csoport parancsnoka, BoRKANYUK Kárpátalján, Körösmezőn született. Belépett a Csehszlovák Kommunista Pártba, egy ideig a párt országgyűlési képviselője is volt. Csehszlovákia széthullása után a Szovjetunióba menekült. HÁBERMANN Sámuel parancsnokhelyettes, szintén 1939-ben emigrált a Szovjetunióba. Önként jelentkezett a Vörös Hadseregbe, ahol ejtőernyős kiképzést kapott. DÉKÁN József Spanyolországban harcolt a köztársaságiak oldalán, onnan került a Szovjetunióba. A csoport tagja volt még MozsARovics Mihály, KöváGó Gyula és Vitalij Alekszandrovics RAzovszKiJ orosz mérnökszázados, aki korábban rádiós oktatótiszt volt a partizániskolán, míg be nem osztották BORKANYUK csoportjába

GAZSI: A Borkanyuk-partizáncsoport. 571-574.p.

${ }^{65}$ HIM.HL. VKF op.cit. Eln. 1. 4114/1942. ; KÜHNRICH: 87.p.

${ }^{66}$ HIM.HL. VKF op.cit. Eln. 4117/1942. ； HIM.HL. HM.Eln. op.cit. 13. 35 580/1942. ； PUSKAS: 219.p.

${ }^{67}$ Elöször HABERMAN, DÉKÁN és MAZAROVICS ugrott utoljára — a feleszerelés ledobása után — RAZIOVSZKIJ, BORKANYUK és KÖVÁGÓ ugrott.

HARSÁNYI: op.cit. 89-96.p. ; GAZSI: A Borkanyuk-partizáncsoport. op.cit. 581.p.

${ }^{68}$ HIM. HL. VKF op.cit. Eln. 1. Napi helyzetjelentés 1942. január 4.

${ }^{69}$ A magyar hatóságok KőVÁGÓ Gyula ejtőernyőst, a németek pedig HÁBERMANN Sámuelt fogták el.

GAZSI: A Borkanyuk-partizáncsoport. op.cit. 581-582.p.

${ }^{70}$ HIM. HL VKF op.cit. Eln. 1. 4114/1942. , 3806/M/1942.

${ }^{71}$ Az elfogott partizán DÉKÁN József volt.

HIM.HL. HM.Eln. op.cit. 13. 35 580. ; VADÁSZ: 36.p.

${ }^{72}$ A magát megadó ejtőernyős a RAZOVSZKIJ a csoport rádiósa, a tüzharcban elesett ejtőernyős pedig MozSAROVICS Mihály volt.

HIM.HL. VKF op.cit. Eln. 1. Napi helyzetjelentés 1942. január 9., január 10.

${ }^{73}$ PATAKY - ROZSOS - SÁRHIDAI: op.cit. 78.p. ; HARSÁNYI: op.cit. 89.p. ; KoSZTYÓ: 77.p.

${ }^{74}$ HIM.HL. VKF op.cit. Eln. 1. 4152/1942. ; GAZSI: A Borkanyuk-partizáncsoport op.cit. 578.p.

${ }^{75}$ HIM.HL. VKF op.cit. Eln. 2. 32 528/1941.

${ }^{76}$ Oktatás az örsön: 70-74.p. ; TOLNAY: 151-154.p.

77 1942. III. 22-én például Nagyvárad és Székelyhíd térségében láttak leszálló ejtőernyőst, az esetekről azonban később beigazolódott, hogy csak katonai léggömbről vagy világító bombáról volt szó.

HIM.HL. VKF op.cit. Eln. 1. 4436/1942., 4590/1942., 4604/1942.

${ }^{78}$ Loc.cit. Eln. 1. 4596/1942.

${ }^{79}$ Ennek részét képezte az úgynevezett légoltalmi Budapest, tehát a föváros és tágabb körzetének 3 kerülete: Pest-Észak (Dunakeszit, Kerepest, Pécelt, Maglódot is beleértve), Pest-Dél (Kispest, Vecsés, Üllö határától, Dunavarsányig és Tökölig), és Buda (Törökbálint, Bia, Budakeszi, Pesthidegkút területével együtt).

Az ejtöernyös elháritás (ejel.) szabályozása az I. hadtest területén. a., c. mell.

${ }^{80}$ HIM.HL. HM.Eln. op.cit. 1/b. 3076/M/1942. 
${ }^{81}$ HIM.HL. VKF op.cit. Eln. 1. Napi helyzetjelentés 1942. április 13. ; PARÁDI: A két világháború közötti Magyar Királyság rendvédelme. 87-90.p. ; Idem: Rendvédelem karhatalom 1867-1945. ; Idem: Karhatalom a polgári magyar állam rendvédelmében 1867-1945. ; Idem: A magyar rendvédelem 1919-1941. 59-73.p.

${ }^{82}$ MNL.OL. K-150. BM 4486. cs. 1942-XVIII-16. ; PARÁdI: A magyar Királyi Csendörség. Az elsö magyar polgári, központositott közbiztonsági örtestület 1881-1945. 116-117.p.

${ }^{83}$ HIM.HL. HM.Eln. op.cit. 1/b. 3076/M/1942.

${ }^{84}$ KOSZTYÓ: op.cit. 79.p. ; PUSKAS: op.cit. 231.p.

\section{Forrás- és irodalomjegyzék (a jegyzetekben alkalmazott röviditések oldása):}

\section{MONOGRÁFIÁK, KISMONOGRÁFIÁK ÉS HASONLÓ JELLEGŰ KÖTETEK}

\section{KÜHNRICH}

(65.;)

PARÁDI: A magyar Királyi Csendörség. Az elsö magyar polgári, központositott közbiztonsági örtestület 18811945.

(25.;82.;)

PATAKY - ROZSOS - SÁRHIDAI

(6.;29.;73.;)

PUSKAS

(66.;84.;)

REKTOR

SALY

(51.;)

VADÁSZ

(71.;)

\section{TANULMÁNYOK}

GAZSI: Ejtőernyős partizántevékenység és elhárítás Magyarországon 1941-ben. (1.;10.;19.;22.;27.;30.;32.;38.;40.; 44.;63.;)

GAZsI: A Borkanyuk-partizáncsoport. (64.;67.;69.;74.;)

KosZTYÓ

(73.;84.;)

KuN

(21.;)

PARÁDI: A két világháború közötti Magyar Királyság rendvédelme. (81.;)

PARÁDI: Rendvédelem karhatalom $1867-1945$

(81.,)

PARÁDI: Karhatalom a polgári magyar állam rendvédelmében 1867-1945.

(81.;)
KÜHNRICH, Heinz: Partizánháború Európában 1939-1945. [Der Patisanenkrieg in Europa.] Ford.: PoRga Lajos. Budapest, 1973, Zrínyi Katonai Kiadó. 335 p.

PARÁDI József: A Magyar Királyi Csendörség. Az elsö magyar polgári, központositott közbiztonsági őrtestület 1881-1945. Budapest, 2012, Szemere Bertalan Magyar Rendvédelem-történeti Tudományos Társaság. 281 p. HUISBN 978963084794 0. /A magyar rendvédelem-történet öröksége, $2 . /$ HU-ISSN 2062-8447.

- PATAKy Iván - Rozsos László - SÁRhIDAi Gyula: Légi háború Magyarország felett.

I.köt. Debrecen, 1992, Zrínyi Kiadó. 271 p. HU-ISBN 9633271541.

II.köt. Budapest, 1992, Zrínyi Kiadó. 361 p. HU-ISBN 9633221630.

PUSKAS, Andrej Ivanovics: Vengrija v gody vtoroj mirovoj vojny. [Magyarország a II. világháború idején.] Moszkva, 1966, Nauka. 524 p. RU-ISBN —

ReKTOR Béla: A Magyar Királyi Csendőrség oknyomozó története. Cleveland, Ohio, USA, 1980, Árpád Könyvkiadó Vállalat. 552 p. USA-ISBN 0934214018 .

SAly Dezső: Szigorúan bizalmas! Fekete-könyv: 1939-1944. Budapest, 1945, Anonymus Kiadó. 702 p.

VADÁSz Ferenc: Legenda nélkül. Száz partizán és ellenálló története. Budapest, 1975, Móra Kiadó. 247 p. HU-ISBN 9631102459.

GAZSI József: Ejtőernyő partizántevékenység és elhárítás Magyarországon 1941-ben. Hadtörténelmi Közlemények, LXXXIX.évf. (1976) 3.sz. 494526.p. HU-ISSN 0017-6540.

GAZsi József: A Borkanyuk-partizáncsoport. Hadtörténelmi Közlemények, XCIV.évf. (1981) 4.sz. 569-596.p. HU-ISSN 0017-6540.

- KosZTYÓ Gyula: Kommunista ejtőernyős partizán-bevetések Kárpátalján (1942-1944). Együtt, XV.évf. (2013) 6.sz. 74-84.p. HU-ISSN — Lapengedélyszám: $3 \mathrm{TN}^{0} 188$.

KUN József: A német hadvezetés magyarországi politikájához, 1941. június - július. Hadtörténelmi Közlemények, CIII.évf. (1990) 4.sz. 129-150.p. HU-ISSN 0017-6540.

PARÁDI József: A két világháború közötti Magyar Királyság rendvédelme. Rendvédelem-történeti Füzetek (Acta Historiae Praesidii Ordinis), XVIII. évf. (2010) 21. sz. 85-100.p. HU-ISSN 1216-6774. A tanulmány korábbi változata 2007. október 5-én Budapesten hangzott el a Szemere Bertalan Magyar Rendvédelem-történeti Tudományos Társaság által szervezett rendvédelem-történeti tudományos konferenciasorozatnak , A magyar rendvédelem fejlödése a XIX-XX. században” címü XXI. konferenciáján. A publikált tanulmány az előadás javított, bővített és átdolgozott változata.

PARÁDI József: Rendvédelem karhatalom 1867-1945. Rendvédelem-történeti Füzetek (Acta Historiae Praesidii Ordinis), XX. évf. (2011)23. sz. 111-123.p. HUISSN 1216-6774. A tanulmány korábbi változata 2009. október 9.-én Budapesten hangzott el, a Szemere Bertalan Magyar Rendvédelem-történeti Tudományos Társaság által szervezett rendvédelem-történeti tudományos konferenciasorozatnak „A kiegyezéstöl az ezredfordulóig felszámolt országos hatáskörü magyar rendvédelmi testületek." címü XXIII. konferenciáján. A publikált tanulmány az előadás javított, bővített és átdolgozott változata.

PARÁDI József: Karhatalom a polgári magyar állam rendvédelmében 1867-1945. Rendvédelem-történeti Füzetek (Acta Historiae Praesidii Ordinis), XXVI.évf. (2016) 52.sz. 83-94.p. HU-ISSN 1216-6774. 
PARÁDI: A magyar rendvédelem 19191941.

(81.;)

\section{CIKKEK}

Fel kell készülni orosz ejtőernyős támadásra.

(15.;)

FERENCZI

(45.;48.;50.;)

Hogyan küzdjük le az ellenség ejtőernyőseit?

(15.;)

Hogyan kell védekezni ejtőernyősök ellen? (58.;)

A magyar légoltalom hírei.

(12.;)

Oktatás az örsön.

(76.;)

Örzik a lábon álló termést.

(12.;)

TOLNAY

(76.;)

\section{DOKUMENTUMKIADVÁNYOK}

\author{
HARSÁNYI \\ (25.;67.;73.;) \\ MÁRKUS - SZINAI - VÁSÁRHELYI \\ (51.;)
}

\section{SZABÁLYZATOK}

Ejtőernyős elháritás.

(1.;8.;11.;36.;)

Az ejtőernyős elháritás (ejel.) szabá-

lyozása az I. hadtest területén.

(79.;)

\section{LEVÉL- IRAT ÉS DOKUMENTUMTÁRI GYÜJTEMÉNYEK}

HIM.HL. HM.Eln.

(4.;5.;6.;9.;14.;24.;35.;66.;71.;80.;83.;)

HIM.HL. TGY

(7.;18.;19.;26.;)

HIM.HL. VKF

(2.;3.;4.;5.;7.;10.;13.;17.;20.;21.;24.;

25.;26.;28.;31.;33.;37.;39.;42.;46.;

49.;54.;57.;59.;60.;61.;62.;65.;66.;

68.;70.;72.;74.;75.;77.;78.;81.;)

HIM.HL 10. gy.dd.

(13.;41.;52.;)

MNL.OL. K-149.

$(16 . ; 29 . ; 34 . ; 43 . ; 46 . ; 47 . ; 53 . ; 55 . ; 56 . ;)$

MNL.OL. K-150.

(82.;)

MNL.OL. K-428

(35.;51.;)

\section{JOGSZABÁLYOK}

1939/II.tc.

(8.;)

194 700/1941. (VII. 11.) BM.r.

(12.;) 314-316.p. 230.p.
PARÁDI József: A magyar rendvédelem 1919-1941. Rendvédelem-történeti Füzetek (Acta Historiae Praesidii Ordinis), XXVII.évf. (2017) 54.sz. 59-92.p. HU-ISSN 1216-6774.

- Fel kell készülni orosz ejtőernyős támadásra. Délvidéki Független Hirlap, III.évf. 1941. június 28. 2.p.

- Ferenczi Márton: Orosz ejtőernyős elfogása. Csendőrségi Lapok, XXXII.évf. (1942) 19.sz. 609-611.p.

Hogyan küzdjük le az ellenség ejtőernyőseit? Szegedi Új Nemzedék, XXIII.évf. (1941) június 27. 7.p.

— Hogyan kell védekezni ejtőernyősök ellen? Riadó, V.évf. (1941) 19.sz.

A magyar légoltalom hírei. Légoltalmi Közlemények, III.évf. (1941) 14.sz.

- Oktatás az őrsön. (Szerkesztőségi közlemény.) Csendőrségi Lapok, XXXII.évf. (1942) 3.sz. 70-74.p.

- O Örzik a lábon álló termést. Békés Megyei Hírlap, X.évf. (1941) június 4. 2.p.

TOLNAY Lajos: Ejtőernyősök és légi gyalogság. Csendőrségi Lapok, XXXII.évf. (1942) 5.sz. 151-154.p.

- HARSÁNYi László (szerk.): Magyar szabadságharcosok a fasizmus ellen. Dokumentumok a magyar antifasiszta ellenállási mozgalom történetéböl. Budapest, 1969, Zrínyi Katonai Kiadó. 906 p. HU-ISBN -

- MÁRKus László - SzinAi Miklós - VÁSÁRhelyi Miklós (szerk.): Nem engedélyezem! A cenzúra bizottság dossziéjából. Budapest, 1975, Kossuth Könyvkiadó. 447 p. HU-ISBN 9630902834.

— Ejtöernyös elháritás. (segédlet). Kolozsvár, 1941, M. kir. kolozsvári IX. honvéd hadtest parancsnoksága - Minerva Irodalmi és Nyomdai Múintézet. 22 p.

Az ejtöernyős elhárítás (ejel.) szabályozása az I. hadtest területén. Budapest, 1942, M. kir. budapesti I. honvéd hadtestparancsnokság. 50 p.

- Hadtörténeti Intézet és Múzeum (HIM) Hadtörténelmi Levéltár (HL) Honvédelmi Minisztérium Elnöki (HM.Eln.) Iratok.

— Hadtörténeti Intézet és Múzeum (HIM) Hadtörténelmi Levéltár (HL) Tanulmánygyüjtemények (TGY)

- Hadtörténeti Intézet és Múzeum (HIM) Hadtörténelmi Levéltár (HL) Vezérkari Fönökség (VKF) Irata.

- Hadtörténeti Intézet és Múzeum (HIM) Hadtörténelmi Levéltár (HL) tízedik gyalog dandár (10. gy.dd.) Iratai.

- Magyar Nemzeti Levéltár (MNL) Országos Levéltár (OL) Belügyminisztérium Reservált (K-149.) Iratai

- Magyar Nemzeti Levéltár (MNL) Országos Levéltár (OL) Belügyminisztérium Általános (K-150) Irata.

- Magyar Nemzeti Levéltár (MNL) Országos Levéltár (OL) Magyar Távirati Iroda Könyomatos (K-428.) Iratai

- 1939/II.tc. a honvédelemről.

194 700/1941. (VII. 11.) BM.r. a mezőgazdasági terményeknek tüzveszély elleni védelméről.

Magyarországi rendeletek tára, LXXV.évf. (1941) I.füzet. 2143-2145.p. 